Supporting Information for

\title{
Ligand-based Reactivity of Oxygenation and Alkylation in Cobalt Complexes Binding with (Thiolato)phosphine Derivatives
}

Yi-Ying Wu ${ }^{\dagger}{ }^{\text {Jia-Cheng Hong }},{ }^{\dagger}$ Ruei-Fong Tsai,${ }^{\perp}$ Hung-Ruei Pan,${ }^{\dagger}$ Bo-Hua

Huang, ${ }^{\dagger}$ Yun-Wei Chiang, ${ }^{\perp}$ Gene-Hsiang Lee, ${ }^{\ddagger}$ Mu-Jeng Cheng, ${ }^{\dagger *}$ Hua-Fen

$\mathrm{Hsu}^{\dagger *}$

†Department of Chemistry, National Cheng Kung University, Tainan 701,

${ }^{\perp}$ Department of Chemistry and Frontier Research Center on Fundamental and Applied Sciences of Matters, National Tsing Hua University, Hsinchu 30o13, and

‡Department of Chemistry, National Taiwan University, Taipei 106, Taiwan.

Corresponding Author

*E-mail: konopka@mail.ncku.edu.tw

*E-mail: mjcheng@mail.ncku.edu.tw

Table of Contents

Figure S1. The ESI-MS spectrum of $\left[\mathrm{Co}(\mathrm{PS} 1)_{2}\right](\mathbf{1})$ in THF. The molecular ion peaks display isotopic distribution at 789.13 $\mathrm{m} / \mathrm{z}$ (inset, top), consistent with the calculated pattern of $\mathrm{C}_{42} \mathrm{H}_{44} \mathrm{CoP}_{2} \mathrm{~S}_{2} \mathrm{Si}_{2}$ formulation (inset, bottom) 5

Figure S2. The UV-vis-NIR spectra of $\left[\mathrm{Co}(\mathrm{PS} 1 ")_{2}\right]$ (1) in $\mathrm{CH}_{2} \mathrm{Cl}_{2}$ with the concentration of $1.27 \times 10^{-4} \mathrm{M}$ and $1.24 \times 10^{-3} \mathrm{M}$ (inset).

Figure S3. The temperature dependence of $\mu_{\text {eff }}$ for $\left[\mathrm{Co}(\mathrm{PS} 1 ")_{2}\right]$ (1) at 1 Tesla

Figure S4. The ${ }^{1} \mathrm{H}$ NMR spectrum of $\left[\mathrm{Co}(\mathrm{PS} 1 \text { " })_{2}\right](\mathbf{1})$ in $\mathrm{CD}_{2} \mathrm{Cl}_{2}$.........6

Figure S5. The X-band EPR spectrum of [Co(PS1" $\left.)_{2}\right](1)$ in 2-MeTHF at $77 \mathrm{~K}$. Fits to the spectrum using EasySpin gave the best-fit parameters for $g(2.9,1.98,1.975)$ and $A(220,30$ and 10 $\mathrm{MHz}$ ).

Figure S6. The electron spin-density plot of $\mathbf{1}$ in a quartet state with a tetrahedral geometry. Top view (left); side view (right). ....7

Figure S7. Top and side views of the contour plots of the spin density for 
the antiferromagnetic doublet state.

Figure S8. The ESI-MS spectrum of [Co(OPS1") $)_{2}$ (2) in $\mathrm{CH}_{2} \mathrm{Cl}_{2}$. The isotopic distribution at $821.12 \mathrm{~m} / \mathrm{z}$ for the experimental pattern (inset, top) and the calculated pattern (inset, bottom). The peak at 1202.21 is associated with the formula of $\left[\mathrm{Co}(\mathrm{OPS} 1 ")_{3}\right]$, likely generated in the chamber of the spectrometer.

Figure S9. The temperature dependence of $\mu_{\mathrm{eff}}$ for $\left[\mathrm{Co}(\mathrm{OPS} 1 \text { ") })_{2}\right]$ (2) at 1 Tesla.

Figure S10. The X-band EPR spectrum of [Co(OPS1") $\left.)_{2}\right]$ (2) in $\mathrm{CH}_{3} \mathrm{CN}$ at $4 \mathrm{~K}$. The theoretical fit to the spectrum using the EasySpin program gave the best-fit parameters for $g(4.8,4.75,2.011)$ and $A(200,400$, and $200 \mathrm{MHz})$.

Figure S11. The ${ }^{1} \mathrm{H}$ NMR spectrum of $\left[\mathrm{Co}\left(\mathrm{OPS} 1{ }^{\prime \prime}\right)_{2}\right](2)$ in $\mathrm{CD}_{2} \mathrm{Cl}_{2} \ldots 10$

Figure S12. Variation of ${ }^{1} \mathrm{H} \mathrm{NMR}$ spectrum of $\left[\mathrm{Co}(\mathrm{PS} 1 \text { ") })_{2}\right](\mathbf{1})$ in $\mathrm{CD}_{2} \mathrm{Cl}_{2}$ with the addition of $\mathrm{O}_{2}$ at different ranges. $20 \sim 50 \mathrm{ppm},-20 \sim-$ 10 ppm (A); -10 0 ppm (B)

Figure S13. The ESI-MS spectra of 1 in $\mathrm{CH}_{2} \mathrm{Cl}_{2}$ with the addition of dioxygen $\left({ }^{16} \mathrm{O}_{2}:{ }^{18} \mathrm{O}_{2}=1: 1\right)$. The data were taken at $0 \mathrm{~h}, 2 \mathrm{~h}$ and $1 \mathrm{~d}$ after dioxygen was added in the solution. The theoretic patterns of $[\mathbf{1}],[\mathbf{1}+\mathrm{O}]$ and $[\mathbf{1}+2 \mathrm{O}]$ with different composition of isotope labeling were also shown.

Figure S14. UV-vis-NIR spectra of [Co(PS1" $\left.)_{2}\right](1)$ in THF $\left(1.3 \times 10^{-4} \mathrm{M}\right)$ under $\mathrm{O}_{2}$ atmosphere.

Figure S15. The X-band EPR spectrum of $\left[\mathrm{Co}(\mathrm{PS} 1 ")_{2}\right](\mathbf{1})$ with the addition of $\mathrm{O}_{2}$ in 2-MeTHF at $77 \mathrm{~K}$. Fits to X-band spectra using EasySpin gave the best-fit parameters for $g$ (2.0361, $2.0167,2.0102), A_{59 \mathrm{Co}}(38,13$, and $56 \mathrm{MHz})$ and $A_{31 \mathrm{P}}(10$, 21 and $26 \mathrm{MHz}$ )

Figure S16. The ${ }^{1} \mathrm{H}$ NMR spectrum of $\left[\mathrm{Zn}\left(\mathrm{PS}^{\prime}\right)_{2}\right]$ in $\mathrm{CD}_{2} \mathrm{Cl}_{2}(\mathrm{~A})$. The ${ }^{1} \mathrm{H}$ NMR spectrum of $\left[\mathrm{Zn}(\mathrm{PS} 1)_{2}\right]$ after the addition of $\mathrm{O}_{2}$ for one day (B) and five days (C). The ${ }^{1} \mathrm{H}$ NMR spectrum of $\left[\mathrm{Zn}(\mathrm{OPS} 1 ")_{2}\right]$ in $\mathrm{CD}_{2} \mathrm{Cl}_{2}(\mathrm{D})$. 13

Figure S17. The ${ }^{31} \mathrm{P}$ NMR spectrum of $\left[\mathrm{Zn}\left(\mathrm{PS}^{\prime \prime}\right)_{2}\right]$ in $\mathrm{CD}_{2} \mathrm{Cl}_{2}(\mathrm{~A})$. The ${ }^{31} \mathrm{P}$ NMR spectrum of $\left[\mathrm{Zn}(\mathrm{PS} 1 \text { " })_{2}\right]$ after the addition of $\mathrm{O}_{2}$ for one day (B) and five days (C). The ${ }^{31}$ P NMR spectrum of $\left[\mathrm{Zn}(\mathrm{OPS} 1 ")_{2}\right]$ in $\mathrm{CD}_{2} \mathrm{Cl}_{2}(\mathrm{D})$. 13

Figure S18. The ${ }^{1} \mathrm{H}$ NMR spectra of $\left[\mathrm{H}\left(\mathrm{PS}^{\prime \prime}\right)\right]$ in $\mathrm{CD}_{2} \mathrm{Cl}_{2}$ with the 
addition of $\mathrm{O}_{2}$

Figure S19. The ${ }^{31} \mathrm{P}$ NMR spectra of $[\mathrm{H}(\mathrm{PS} 1 ")]$ in $\mathrm{CD}_{2} \mathrm{Cl}_{2}$ with the addition of $\mathrm{O}_{2}$

Figure S20. The isotopic distribution at $1011.09 \mathrm{~m} / \mathrm{z}$ in the ESI-MS spectrum of $\left[\mathrm{Co}\left(\mathrm{PS}^{*}\right)_{2}\right]^{-}$(the anion of $\mathbf{3}$ ) in $\mathrm{CH}_{2} \mathrm{Cl}_{2}$. The experiment pattern (inset, top) and the calculated pattern (inset, bottom). 15

Figure S21. The UV-vis-NIR spectrum of $\left[\mathrm{NEt}_{4}\right]\left[\mathrm{Co}\left(\mathrm{PS}_{2} *\right)_{2}\right](\mathbf{3})$ in $\mathrm{CH}_{2} \mathrm{Cl}_{2}$.

Figure S22. The ${ }^{1} \mathrm{H}$ NMR spectrum of $\left[\mathrm{NEt}_{4}\right]\left[\mathrm{Co}(\mathrm{PS} 2 *)_{2}\right](\mathbf{3})$ in $\mathrm{CD}_{2} \mathrm{Cl}_{2}$.

Figure S23. The ${ }^{31} \mathrm{P}$ NMR spectrum of $\left[\mathrm{NEt}_{4}\right]\left[\mathrm{Co}\left(\mathrm{PS} 2^{*}\right)_{2}\right](3)$ in $\mathrm{CD}_{2} \mathrm{Cl}_{2}$.

Figure S24. The ${ }^{1} \mathrm{H}$ NMR spectrum of $\left[\mathrm{Co}(\mathrm{PS} 2 *)\left(\mathrm{PSS}^{\mathrm{CH}} 2 \mathrm{Cl} *\right)\right]$ (4 and 4') in $\mathrm{CD}_{2} \mathrm{Cl}_{2}$. Inset: The ${ }^{1} \mathrm{H}$ NMR spectrum range at 4.0-4.5 ppm and 6.5-8.0 ppm

Figure S25. (A) ESI-MS spectrum of $\left[\mathrm{Co}\left(\mathrm{PS}^{2}\right)\left(\mathrm{PSS}^{\mathrm{CH}} 2 \mathrm{Cl} *\right)\right](\mathbf{4}$ and $\mathbf{4}$ ') obtained from the reaction of $\mathbf{3}$ and $\mathrm{CH}_{2} \mathrm{Cl}_{2}$, showing the isotope distribution at the $1060.09 \mathrm{~m} / \mathrm{z}$. (B) The spectrum obtained from the reaction of $\mathbf{3}$ and $\mathrm{CD}_{2} \mathrm{Cl}_{2}$, showing the isotope distribution at the $1062.09 \mathrm{~m} / \mathrm{z}$.

Figure S26. UV-vis-NIR spectra of complex 3 in $\mathrm{CH}_{3} \mathrm{CN}$ after the addition of 100 equivalents of benzylchloride. The spectrum was monitored over a 7-hour period: the initial (red line), the final spectrum (blue line). 18

Figure S27. UV-vis-NIR spectra of complex 3 in $\mathrm{CH}_{3} \mathrm{CN}$ (red line) after the addition of 100 equivalents of $\mathrm{CH}_{3} \mathrm{I}$ (blue line), and the solution color from reddish-brown change to purple immediately.

Figure S28. The ESI-MS spectrum of complex $\mathbf{3}$ with the addition of 100 equivalents of $\mathrm{CH}_{3} \mathrm{I}$ in $\mathrm{CH}_{3} \mathrm{CN}$. The molecular ion peaks display isotopic distribution at $1041.14 \mathrm{~m} / \mathrm{z}$ (inset: top), consistent with the calculated pattern of $\mathrm{CoC}_{62} \mathrm{H}_{48} \mathrm{P}_{2} \mathrm{~S}_{4}$ formulation (inset: bottom).

Figure S29. The ESI-MS spectrum of complex $\mathbf{3}$ with the addition of 100 equivalents of benzyl chloride in $\mathrm{CH}_{3} \mathrm{CN}$. The molecular ion peaks display isotopic distribution at $1193.20 \mathrm{~m} / \mathrm{z}$ (inset: top), consistent with the calculated pattern of $\mathrm{CoC}_{74} \mathrm{H}_{56} \mathrm{P}_{2} \mathrm{~S}_{4}$ 
formulation (inset: bottom).

Figure S30. UV-vis-NIR spectra of complex 1 in $\mathrm{CH}_{2} \mathrm{Cl}_{2}$ (red line) after the addition of 100 equivalents of $\mathrm{CH}_{3} \mathrm{I}$. The spectrum was taken every 2 hours over a 10-hour period: initial (red line) and $10 \mathrm{~h}$ (blue line).

Table S1. Crystallographic data of [Co $\left.{ }^{\mathrm{II}}\left(\mathrm{PS}^{\prime \prime}\right)_{2}\right](\mathbf{1})$. S20

Table S2. Crystallographic data of $\left[\mathrm{NEt}_{4}\right]\left[\mathrm{Co}^{\mathrm{III}}\left(\mathrm{PS}_{2} *\right)_{2}\right] \cdot 2 \mathrm{CH}_{3} \mathrm{OH} \cdot 0.5 \mathrm{THF}$ $\left(3 \cdot 2 \mathrm{CH}_{3} \mathrm{OH} \cdot 0.5 \mathrm{THF}\right)$.

Table S3. Crystallographic data of $\left[\mathrm{Co}^{\mathrm{III}}\left(\mathrm{PS}^{*} *\left(\mathrm{PSS}^{\mathrm{CH}} 2 \mathrm{Cl} *\right)\right] \cdot 5 \mathrm{CH}_{3} \mathrm{OH}\right.$

$\left(4 \cdot 5 \mathrm{CH}_{3} \mathrm{OH}\right)$. S22

Table S4. Crystallographic data of $[\mathrm{Co}$

$\left(4^{\prime} \cdot \mathrm{CH}_{2} \mathrm{Cl}_{2}\right.$ ). S23

Table S5. Selected bond distances $(\AA)$ and bond angles (deg) of 1......S24

Table S6. Selected bond distances $(\AA)$ and bond angles (deg) of $3 \cdot 2 \mathrm{CH}_{3} \mathrm{OH} \cdot 0.5 \mathrm{THF}$. $\mathrm{S} 24$

Table S7. Selected bond distances $(\AA)$ and bond angles (deg) of $4 \cdot 5 \mathrm{CH}_{3} \mathrm{OH}$

Table S8. Selected bond distances $(\AA)$ and bond angles (deg) of 4' $\mathrm{CH}_{2} \mathrm{Cl}_{2}$. S25 


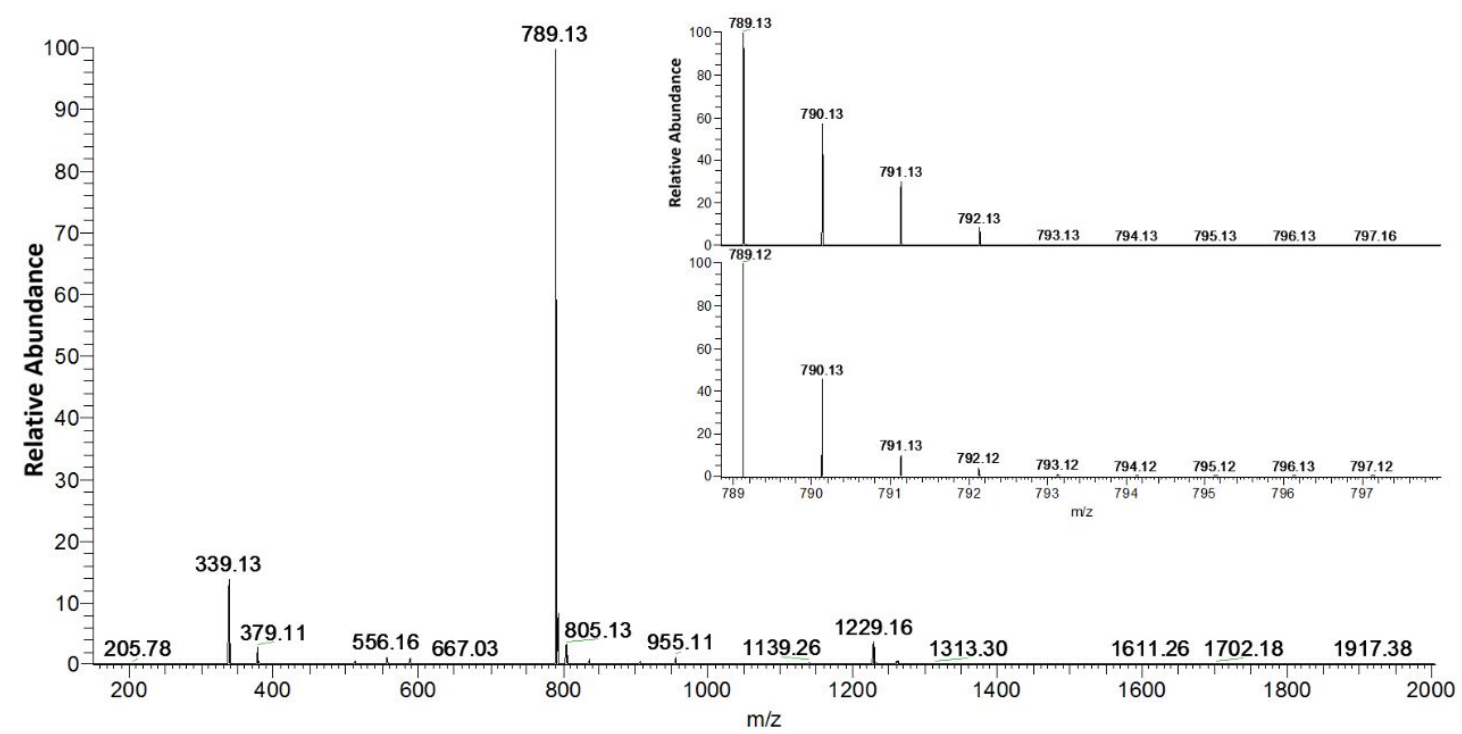

Figure S1. The ESI-MS spectrum of $\left[\mathrm{Co}(\mathrm{PS} 1 ")_{2}\right](\mathbf{1})$ in THF. The molecular ion peaks display isotopic distribution at $789.13 \mathrm{~m} / \mathrm{z}$ (inset, top), consistent with the calculated pattern of $\mathrm{C}_{42} \mathrm{H}_{44} \mathrm{CoP}_{2} \mathrm{~S}_{2} \mathrm{Si}_{2}$ formulation (inset, bottom).

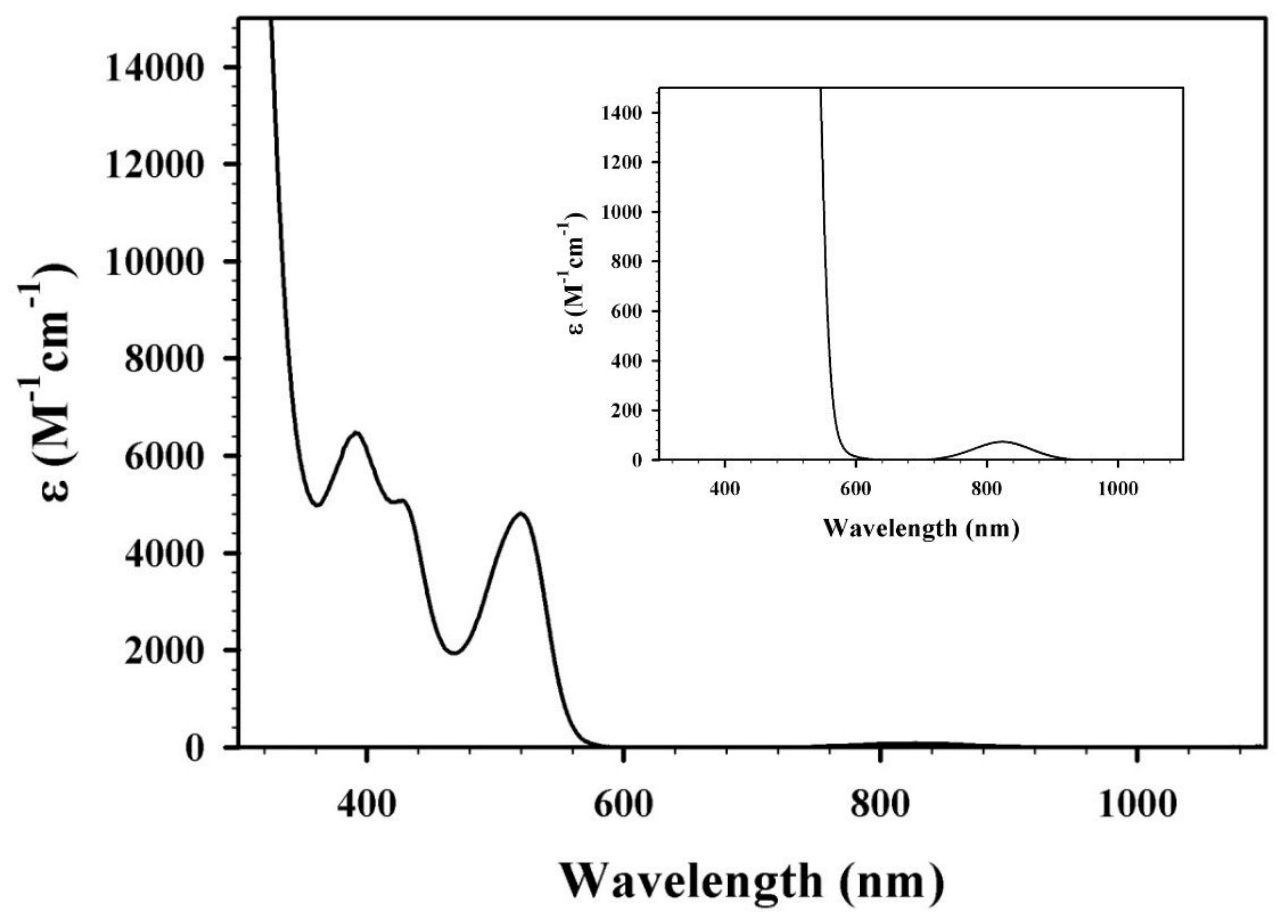

Figure S2. The UV-vis-NIR spectra of [Co(PS1") $\left.)_{2}\right](\mathbf{1})$ in $\mathrm{CH}_{2} \mathrm{Cl}_{2}$ with the concentration of $1.27 \times 10^{-4} \mathrm{M}$ and $1.24 \times 10^{-3} \mathrm{M}$ (inset). 


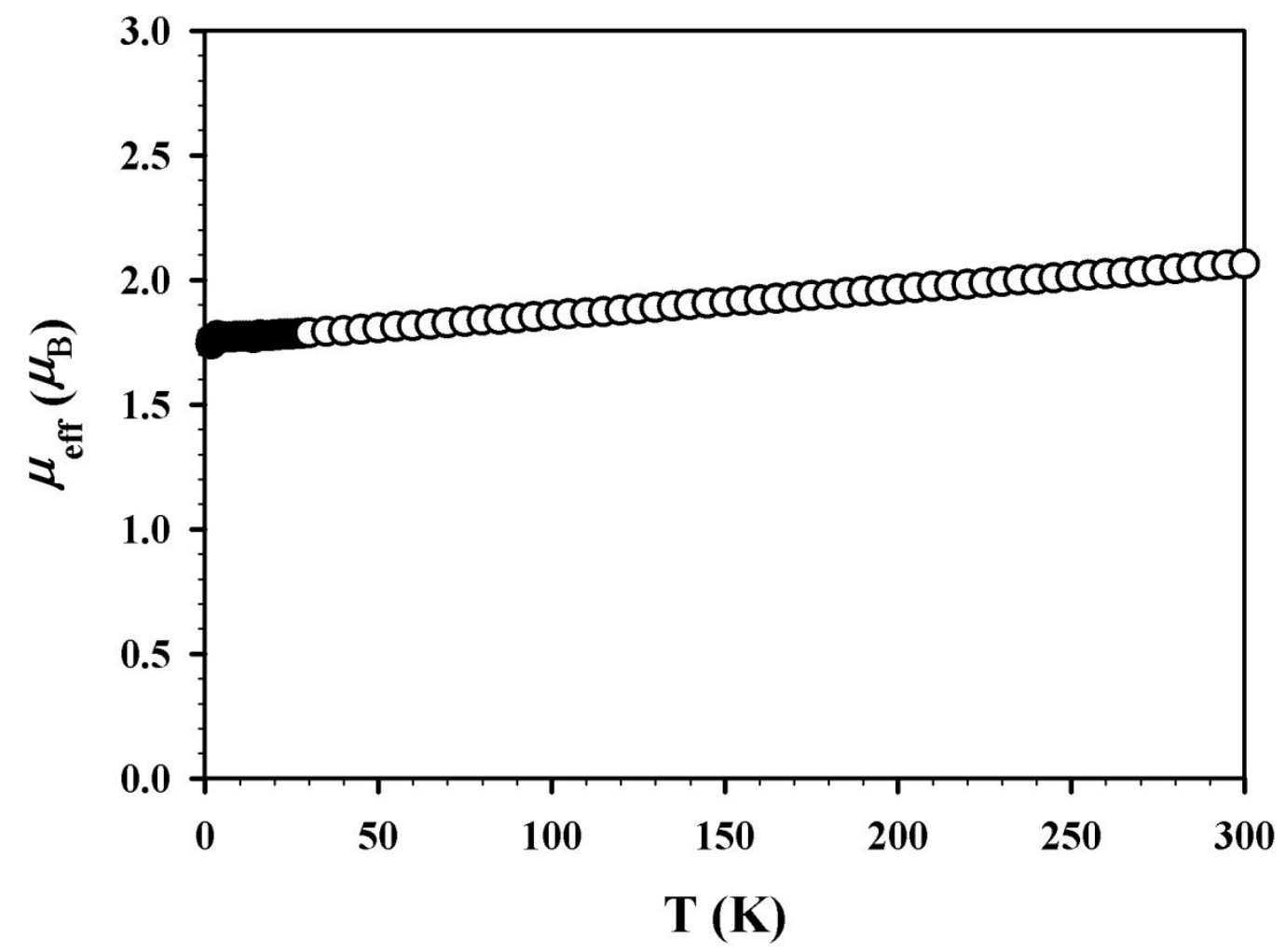

Figure S3. The temperature dependence of $\mu_{\mathrm{eff}}$ for $\left[\mathrm{Co}(\mathrm{PS} 1 \text { ") })_{2}\right]$ (1) at 1 Tesla.

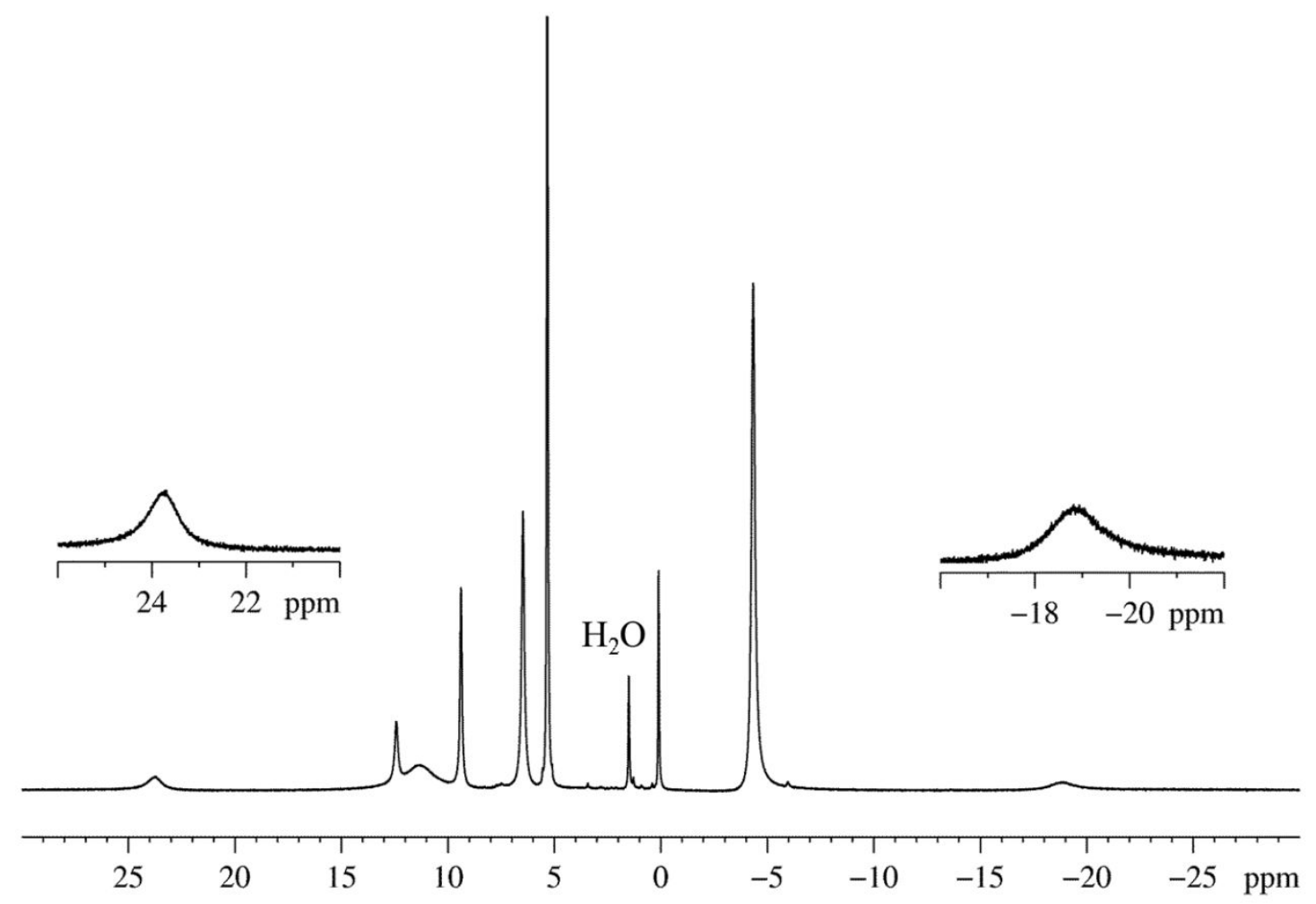

Figure S4. The ${ }^{1} \mathrm{H}$ NMR spectrum of $\left[\mathrm{Co}(\mathrm{PS} 1 ")_{2}\right](\mathbf{1})$ in $\mathrm{CD}_{2} \mathrm{Cl}_{2}$. 


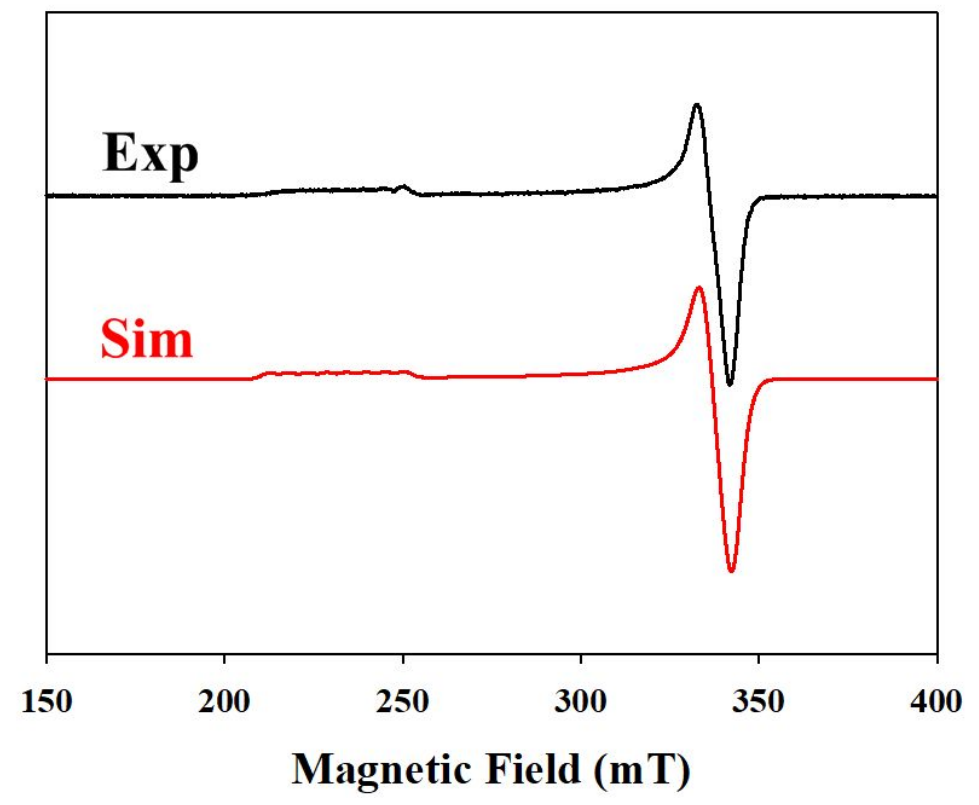

Figure S5. The X-band EPR spectrum of [Co(PS1") $)_{2}$ (1) in 2-MeTHF at $77 \mathrm{~K}$. Fits to the spectrum using EasySpin gave the best-fit parameters for $g(2.9,1.98,1.975)$ and $A(220,30$ and $10 \mathrm{MHz})$.
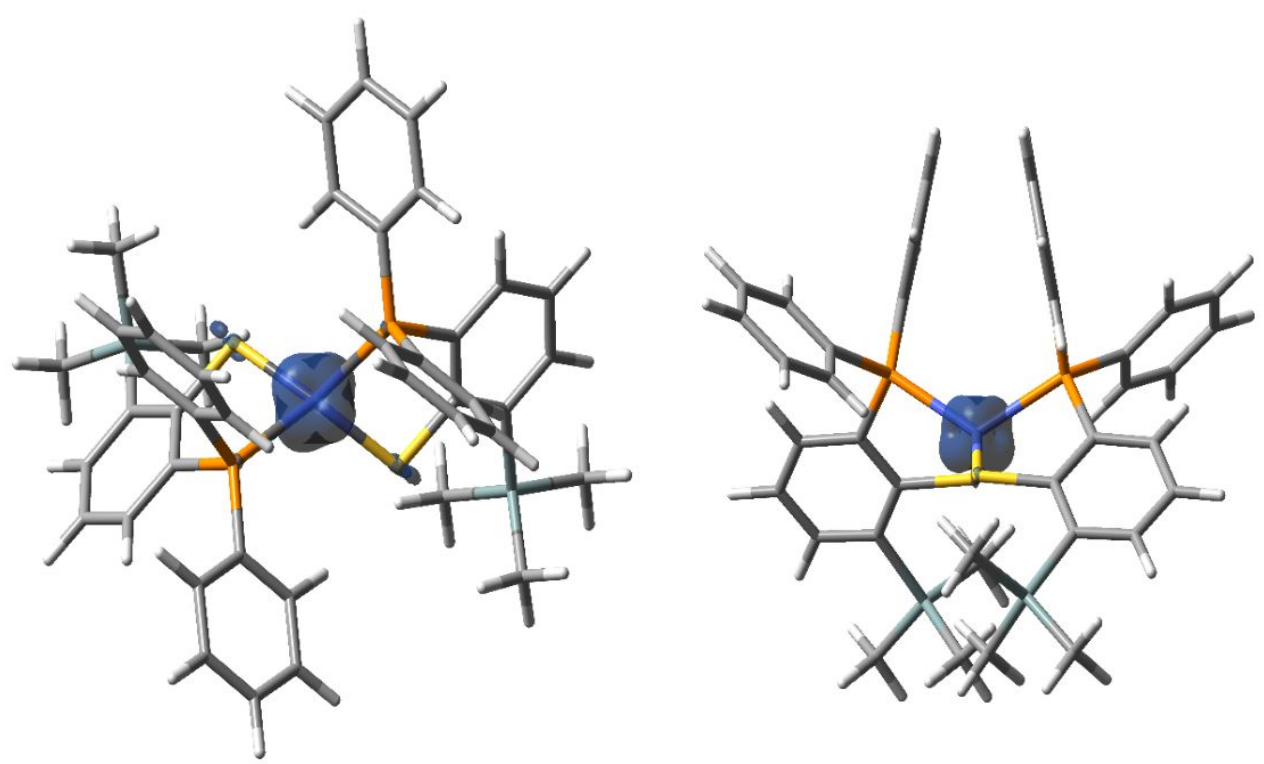

Figure S6. The electron spin-density plot of $\mathbf{1}$ in a quartet state with a tetrahedral geometry. Top view (left); side view (right). 
(a)

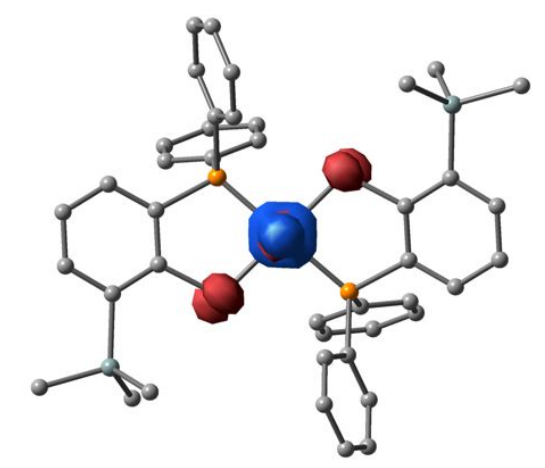

(b)

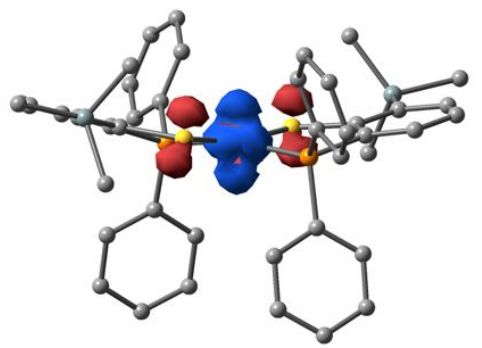

Figure S7. Top and side views of the contour plots of the spin density for the antiferromagnetic doublet state.

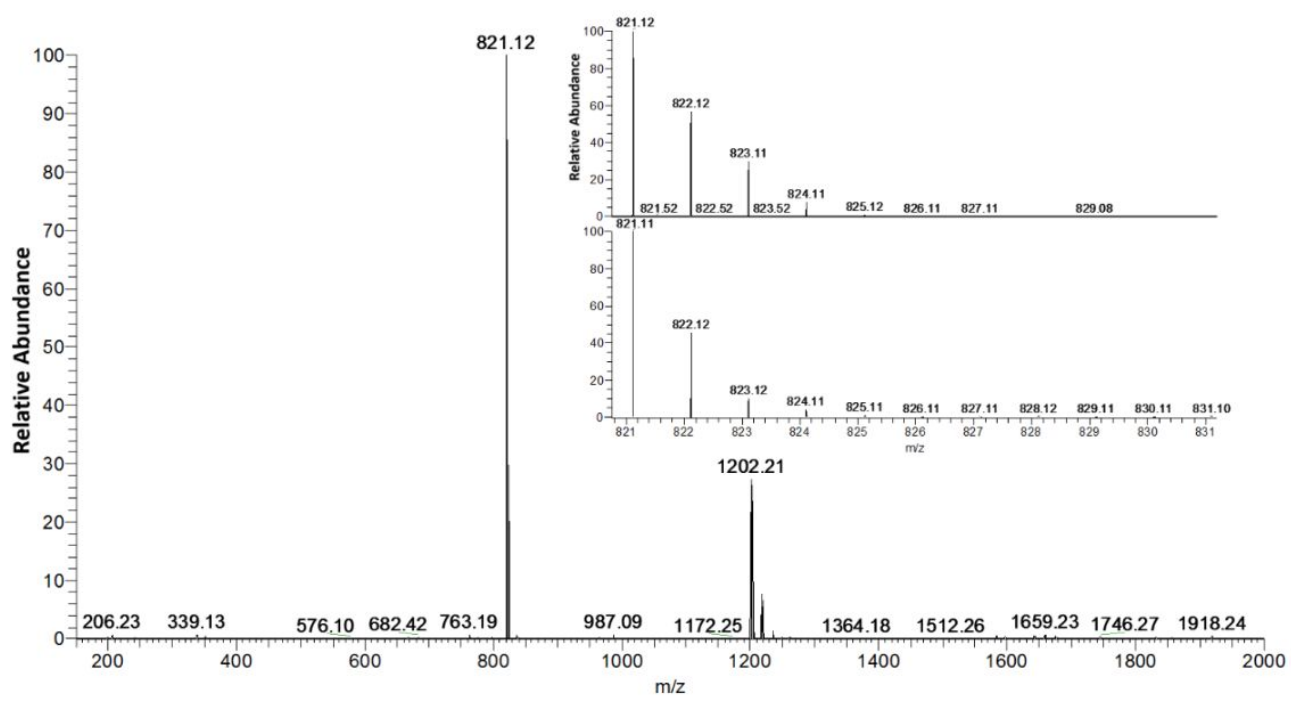

Figure S8. The ESI-MS spectrum of $\left[\mathrm{Co}(\mathrm{OPS} 1 ")_{2}\right]$ (2) in $\mathrm{CH}_{2} \mathrm{Cl}_{2}$. The isotopic distribution at $821.12 \mathrm{~m} / \mathrm{z}$ for the experimental pattern (inset, top) and the calculated pattern (inset, bottom). The peak at 1202.21 is associated with the formula of $\left[\mathrm{Co}(\mathrm{OPS} 1 ")_{3}\right]$, likely generated in the chamber of the spectrometer. 


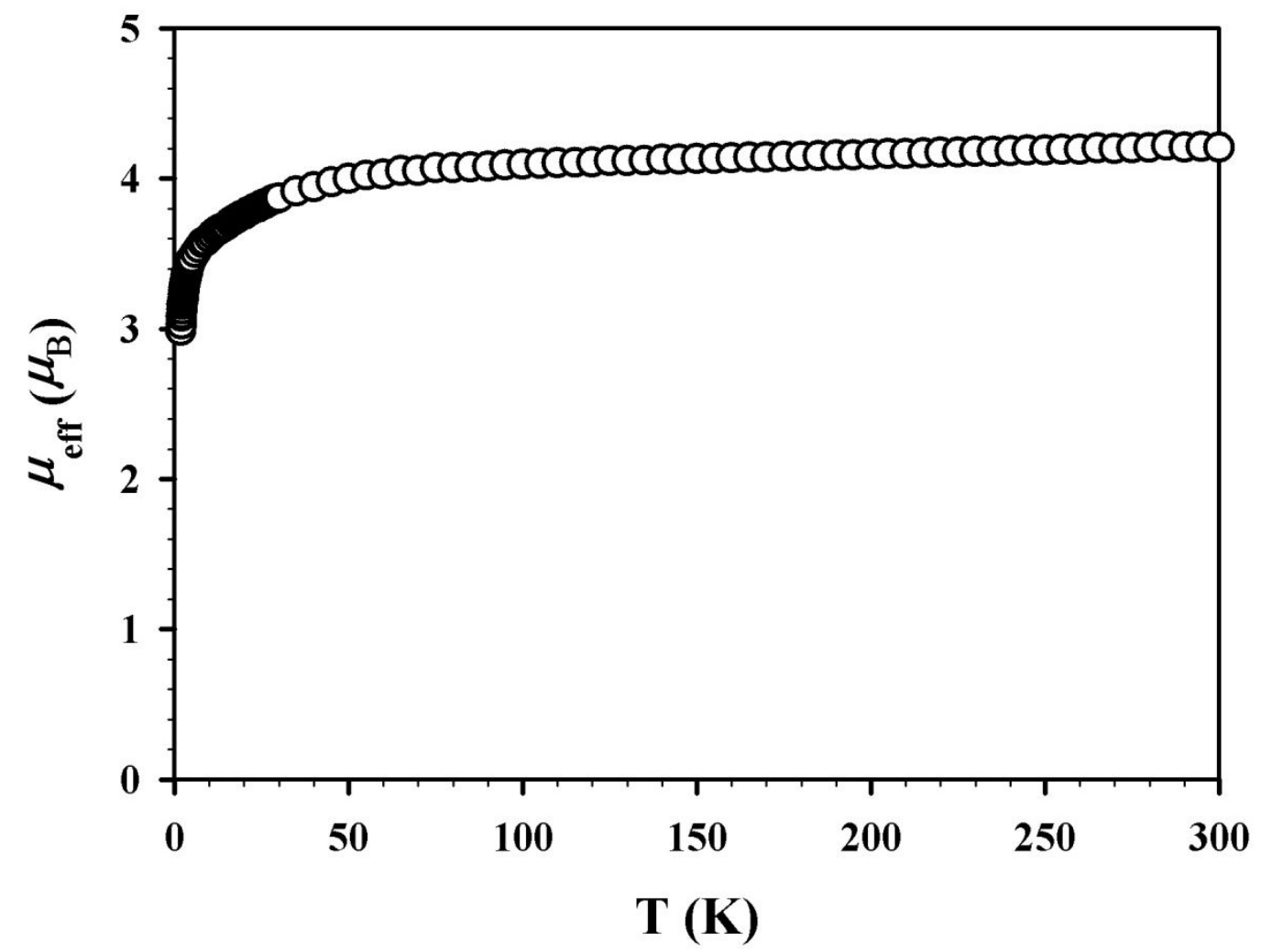

Figure S9. The temperature dependence of $\mu_{\mathrm{eff}}$ for [Co(OPS1”) $)_{2}$ (2) at 1 Tesla.

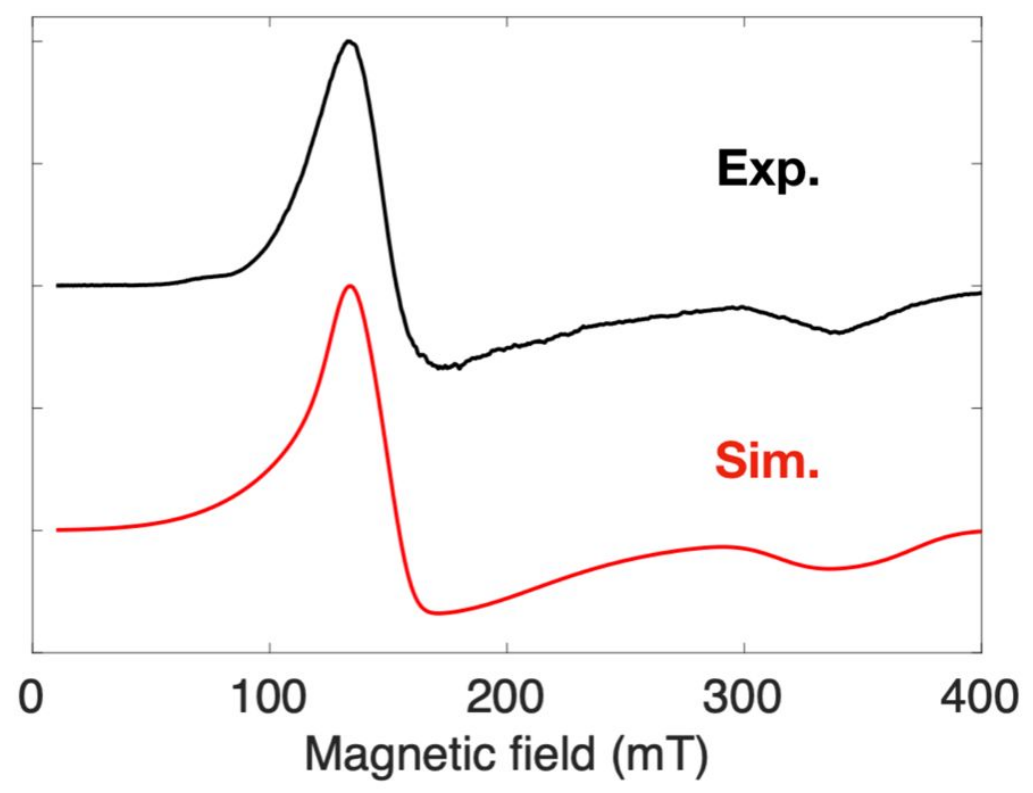

Figure S10. The X-band EPR spectrum of $\left[\mathrm{Co}(\mathrm{OPS1})_{2}\right](2)$ in $\mathrm{CH}_{3} \mathrm{CN}$ at $4 \mathrm{~K}$. The theoretical fit to the spectrum using the EasySpin program gave the best-fit parameters for $g(4.8,4.75,2.011)$ and $A(200,400$, and $200 \mathrm{MHz})$. 


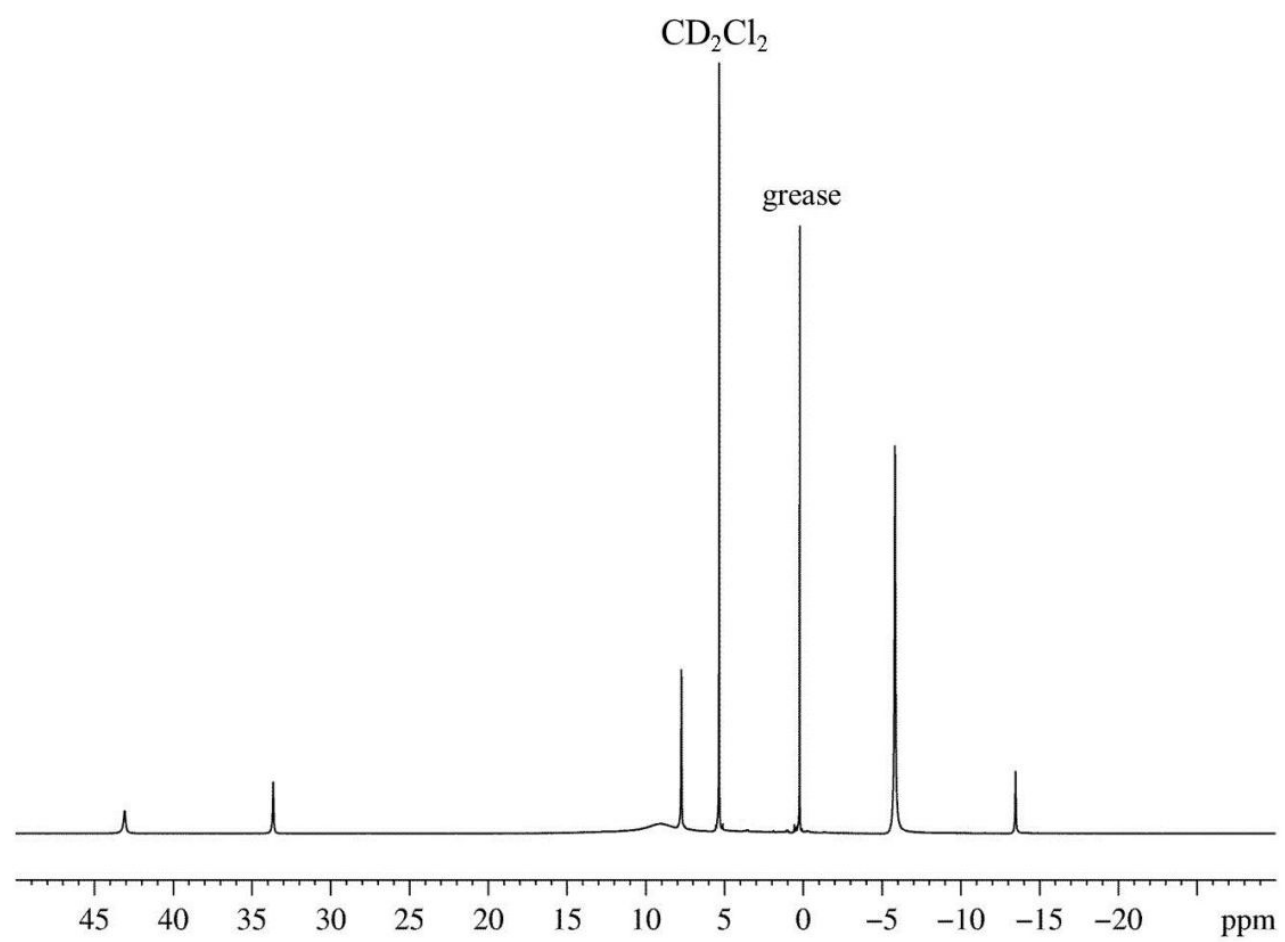

Figure S11. The ${ }^{1} \mathrm{H}$ NMR spectrum of $\left[\mathrm{Co}(\mathrm{OPS} 1 ”)_{2}\right](2)$ in $\mathrm{CD}_{2} \mathrm{Cl}_{2}$.

(A)

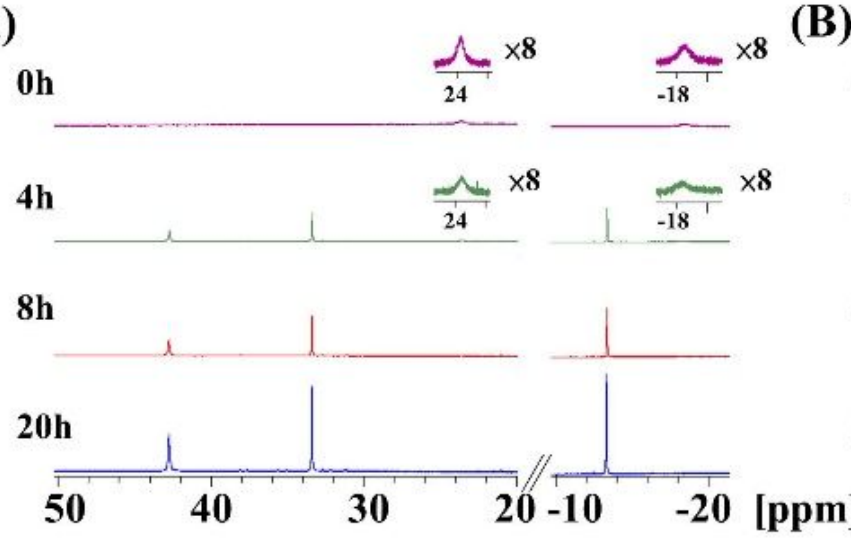

(B)

oh

$4 \mathrm{~h}$

$8 \mathrm{~h}$

$20 h$

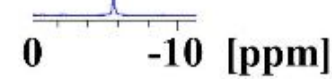

Figure S12. Variation of ${ }^{1} \mathrm{H}$ NMR spectrum of $\left[\mathrm{Co}(\mathrm{PS} 1 \text { ") })_{2}\right](\mathbf{1})$ in $\mathrm{CD}_{2} \mathrm{Cl}_{2}$ with the addition of $\mathrm{O}_{2}$ at different ranges. 20 50 ppm, -20 -10 ppm (A); -10 0 ppm (B). 


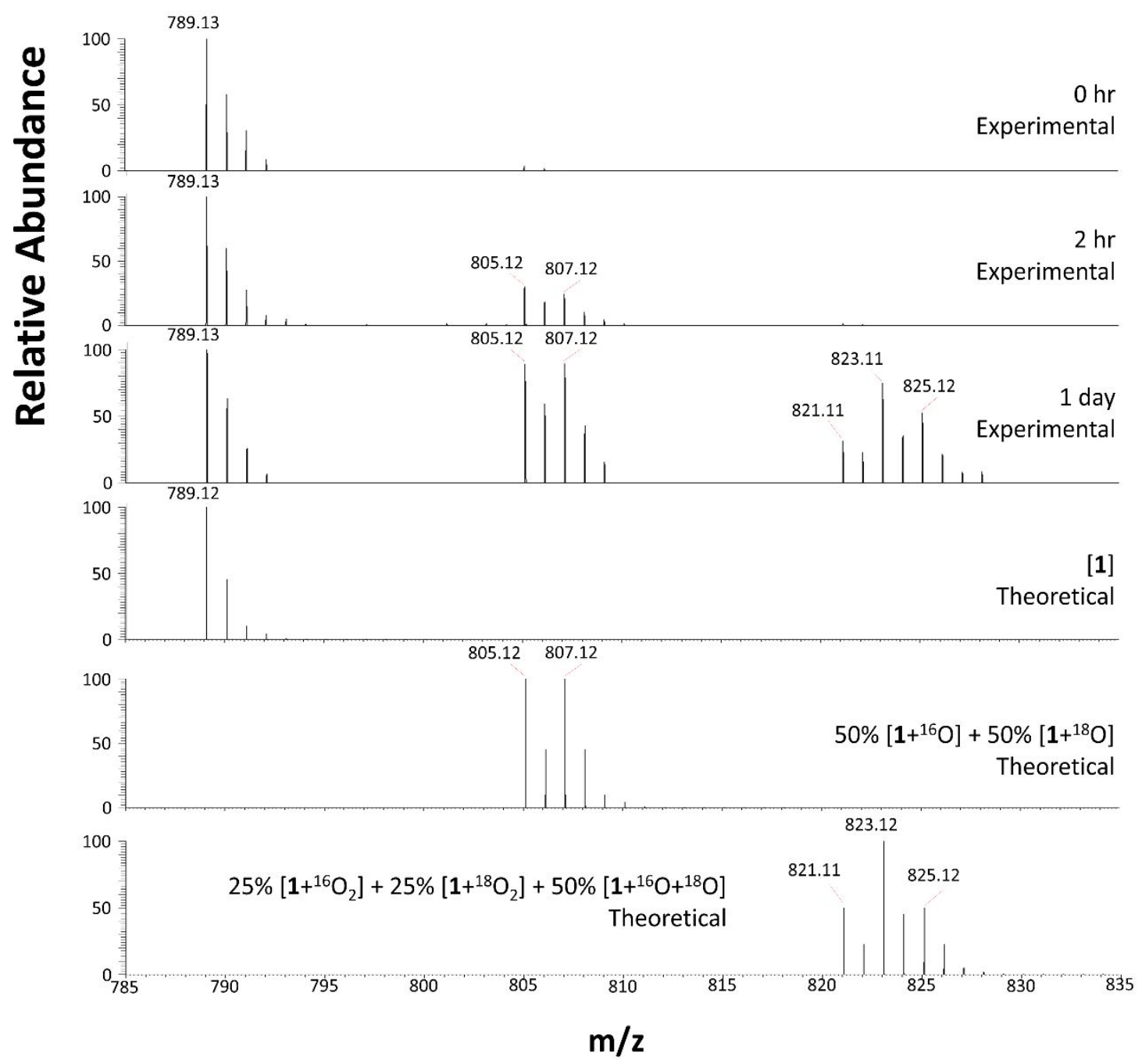

Figure S13. The ESI-MS spectra of 1 in $\mathrm{CH}_{2} \mathrm{Cl}_{2}$ with the addition of dioxygen $\left({ }^{16} \mathrm{O}_{2}:{ }^{18} \mathrm{O}_{2}=1: 1\right)$. The data were taken at $0 \mathrm{~h}, 2 \mathrm{~h}$ and $1 \mathrm{~d}$ after dioxygen was added in the solution. The theoretic patterns of $[\mathbf{1}],[\mathbf{1}+\mathrm{O}]$ and $[\mathbf{1}+2 \mathrm{O}]$ with different composition of isotope labeling were also shown. 


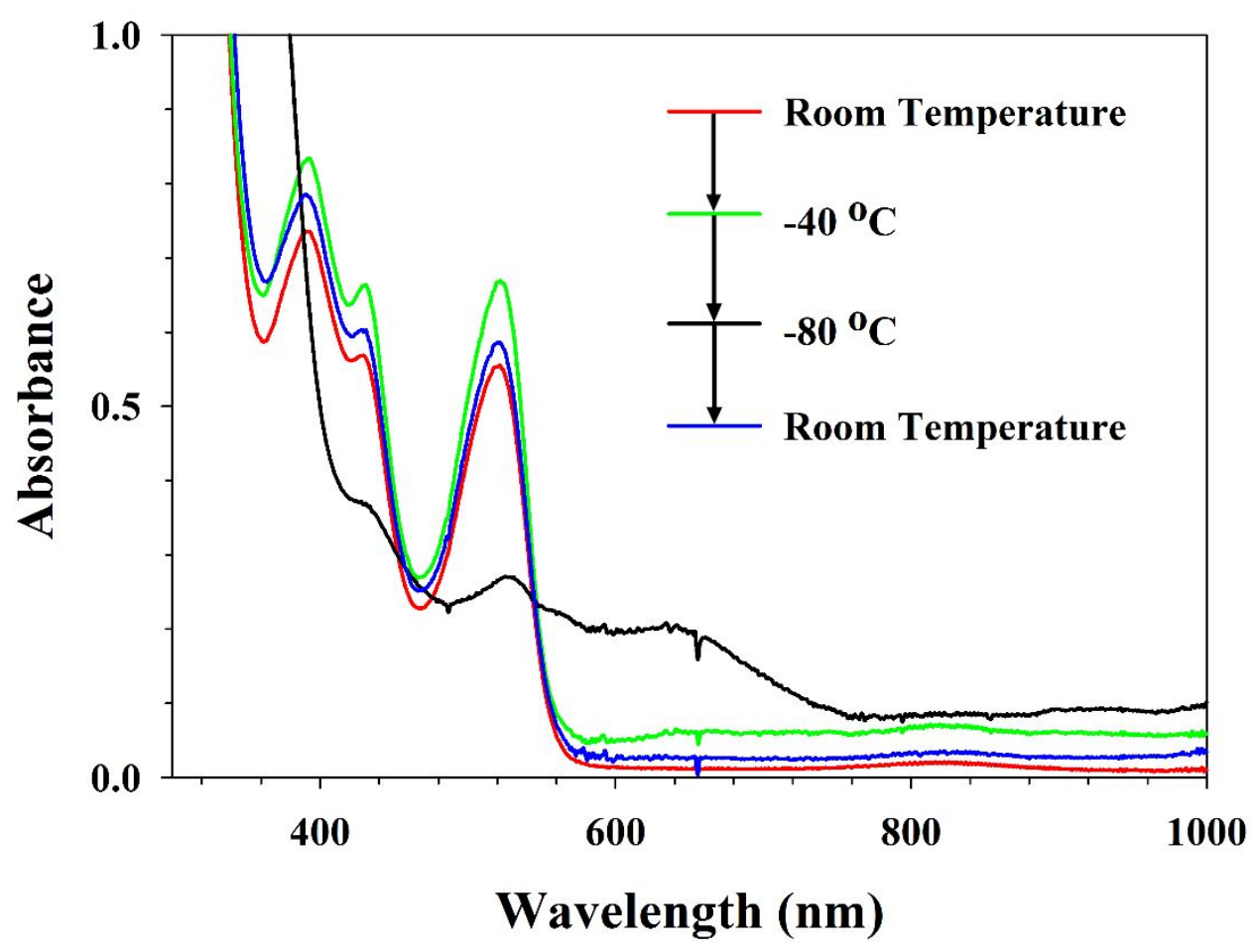

Figure S14. UV-vis-NIR spectra of $\left[\mathrm{Co}(\mathrm{PS} 1)_{2}\right](\mathbf{1})$ in $\mathrm{THF}\left(1.3 \times 10^{-4} \mathrm{M}\right)$ under $\mathrm{O}_{2}$ atmosphere.

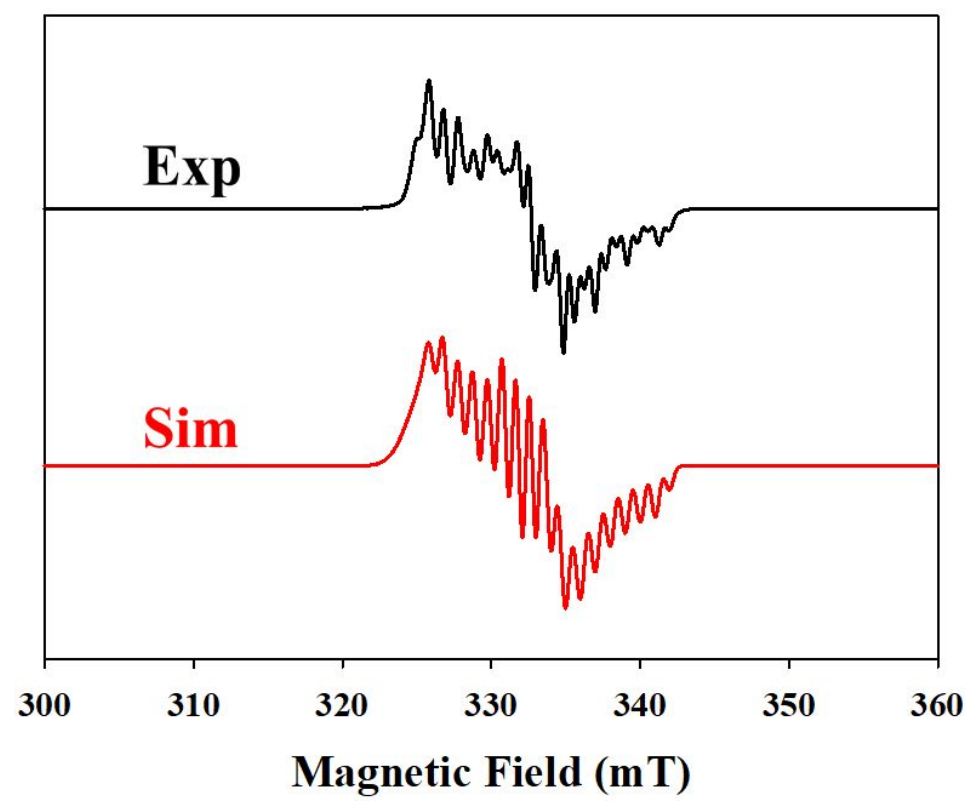

Figure S15. The X-band EPR spectrum of [Co(PS1" $\left.)_{2}\right](1)$ with the addition of $\mathrm{O}_{2}$ in 2-MeTHF at $77 \mathrm{~K}$. Fits to X-band spectra using EasySpin gave the best-fit parameters for $g(2.0361,2.0167,2.0102), A_{59 \mathrm{Co}}(38,13$, and $56 \mathrm{MHz})$ and $A_{31 \mathrm{P}}(10,21$ and 26 $\mathrm{MHz}$ 
(A)
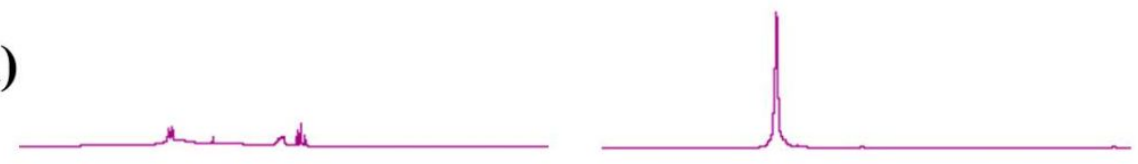

(B)

(C)
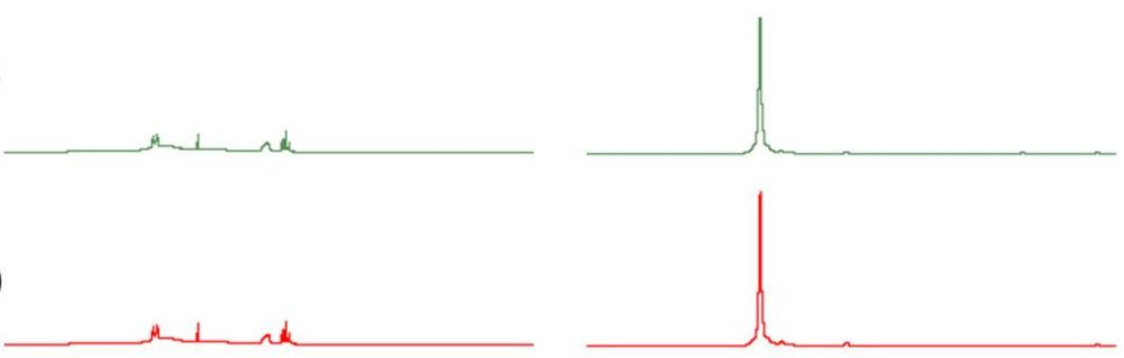

(D)

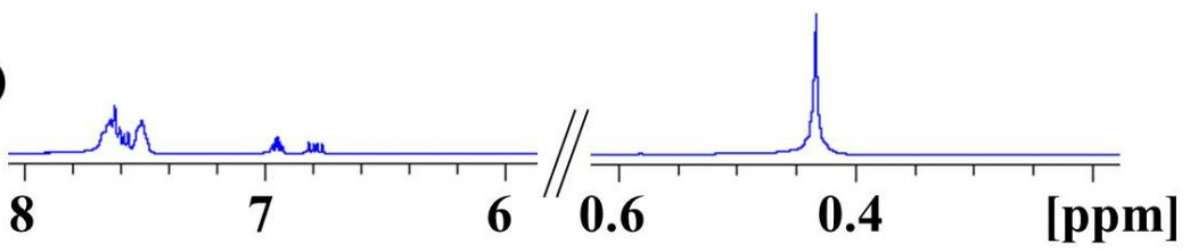

Figure S16. The ${ }^{1} \mathrm{H}$ NMR spectrum of $\left[\mathrm{Zn}(\mathrm{PS1})_{2}\right]$ in $\mathrm{CD}_{2} \mathrm{Cl}_{2}$ (A). The ${ }^{1} \mathrm{H}$ NMR spectrum of $\left[\mathrm{Zn}(\mathrm{PS} 1 \text { " })_{2}\right]$ after the addition of $\mathrm{O}_{2}$ for one day (B) and five days (C). The ${ }^{1} \mathrm{H}$ NMR spectrum of $\left[\mathrm{Zn}(\mathrm{OPS} 1 ")_{2}\right]$ in $\mathrm{CD}_{2} \mathrm{Cl}_{2}$ (D).

(A)

(B)

(C)

(D)

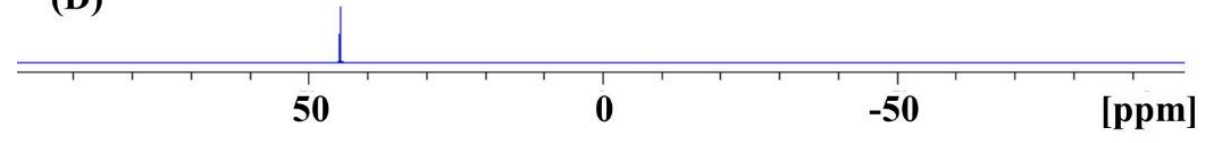

Figure S17. The ${ }^{31} \mathrm{P}$ NMR spectrum of $\left[\mathrm{Zn}(\mathrm{PS1} ")_{2}\right]$ in $\mathrm{CD}_{2} \mathrm{Cl}_{2}$ (A). The ${ }^{31} \mathrm{P}$ NMR spectrum of $\left[\mathrm{Zn}(\mathrm{PS} 1 ")_{2}\right]$ after the addition of $\mathrm{O}_{2}$ for one day (B) and five days (C). The ${ }^{31} \mathrm{P}$ NMR spectrum of $\left[\mathrm{Zn}(\mathrm{OPS} 1 ")_{2}\right]$ in $\mathrm{CD}_{2} \mathrm{Cl}_{2}$ (D). 


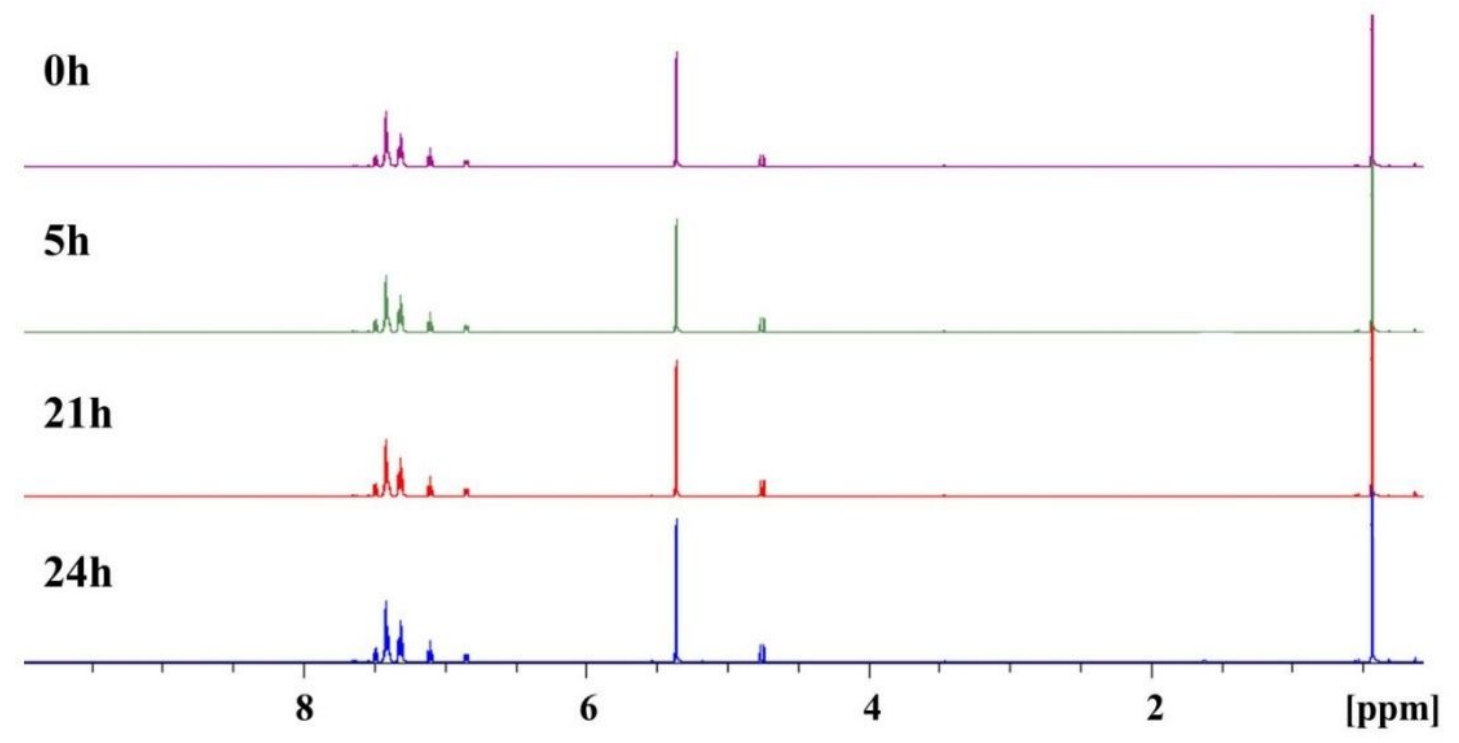

Figure S18. The ${ }^{1} \mathrm{H}$ NMR spectra of $[\mathrm{H}(\mathrm{PS} 1 ")]$ in $\mathrm{CD}_{2} \mathrm{Cl}_{2}$ with the addition of $\mathrm{O}_{2}$.

Oh

$5 h$

\section{1h}

\section{4h}

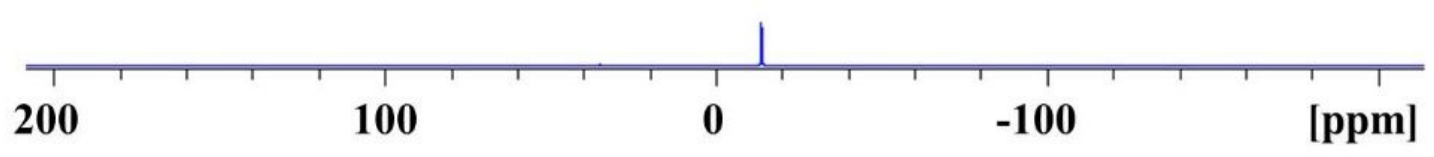

Figure S19. The ${ }^{31} \mathrm{P}$ NMR spectra of $[\mathrm{H}(\mathrm{PS} 1 ")]$ in $\mathrm{CD}_{2} \mathrm{Cl}_{2}$ with the addition of $\mathrm{O}_{2}$. 


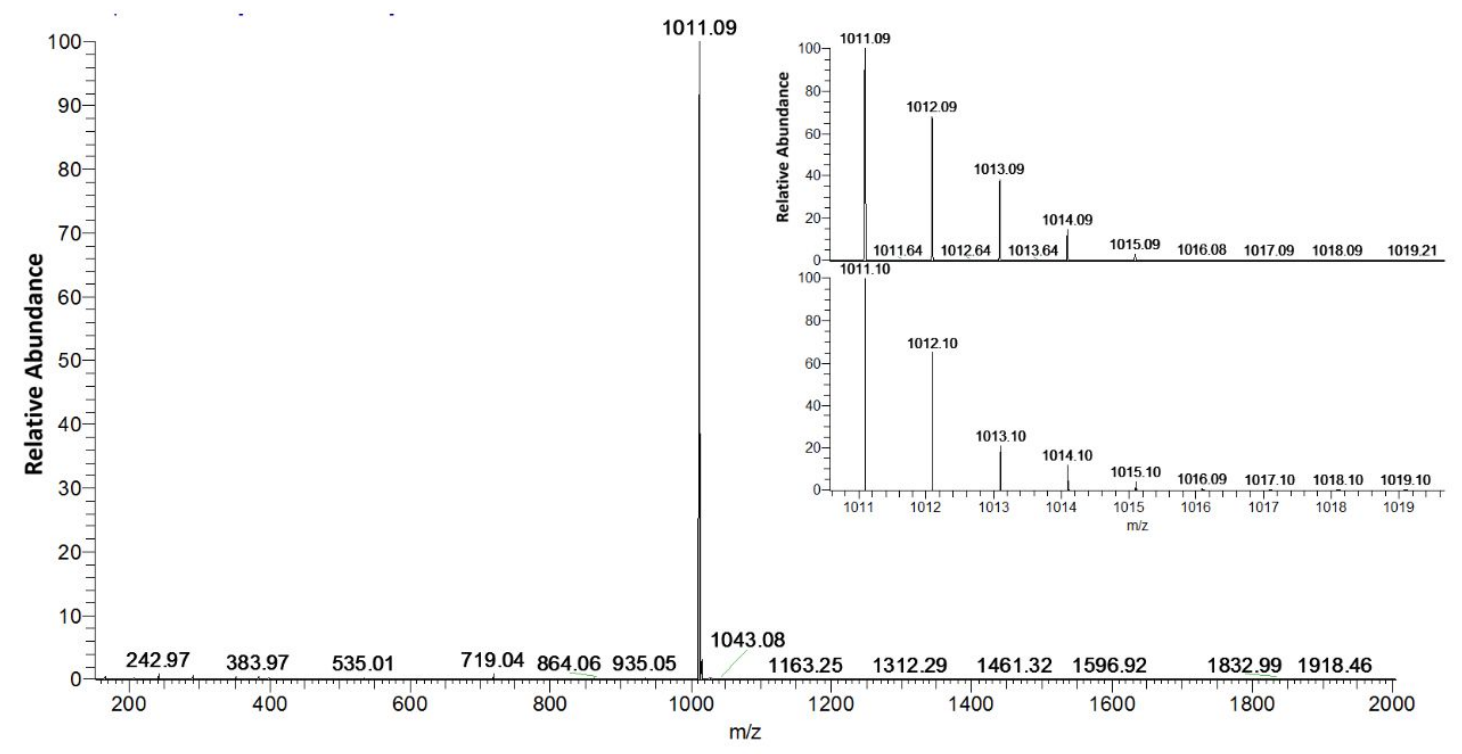

Figure S20. The isotopic distribution at $1011.09 \mathrm{~m} / \mathrm{z}$ in the ESI-MS spectrum of $\left[\mathrm{Co}\left(\mathrm{PS}_{2} *\right)_{2}\right]^{-}$(the anion of 3 ) in $\mathrm{CH}_{2} \mathrm{Cl}_{2}$. The experiment pattern (inset, top) and the calculated pattern (inset, bottom).

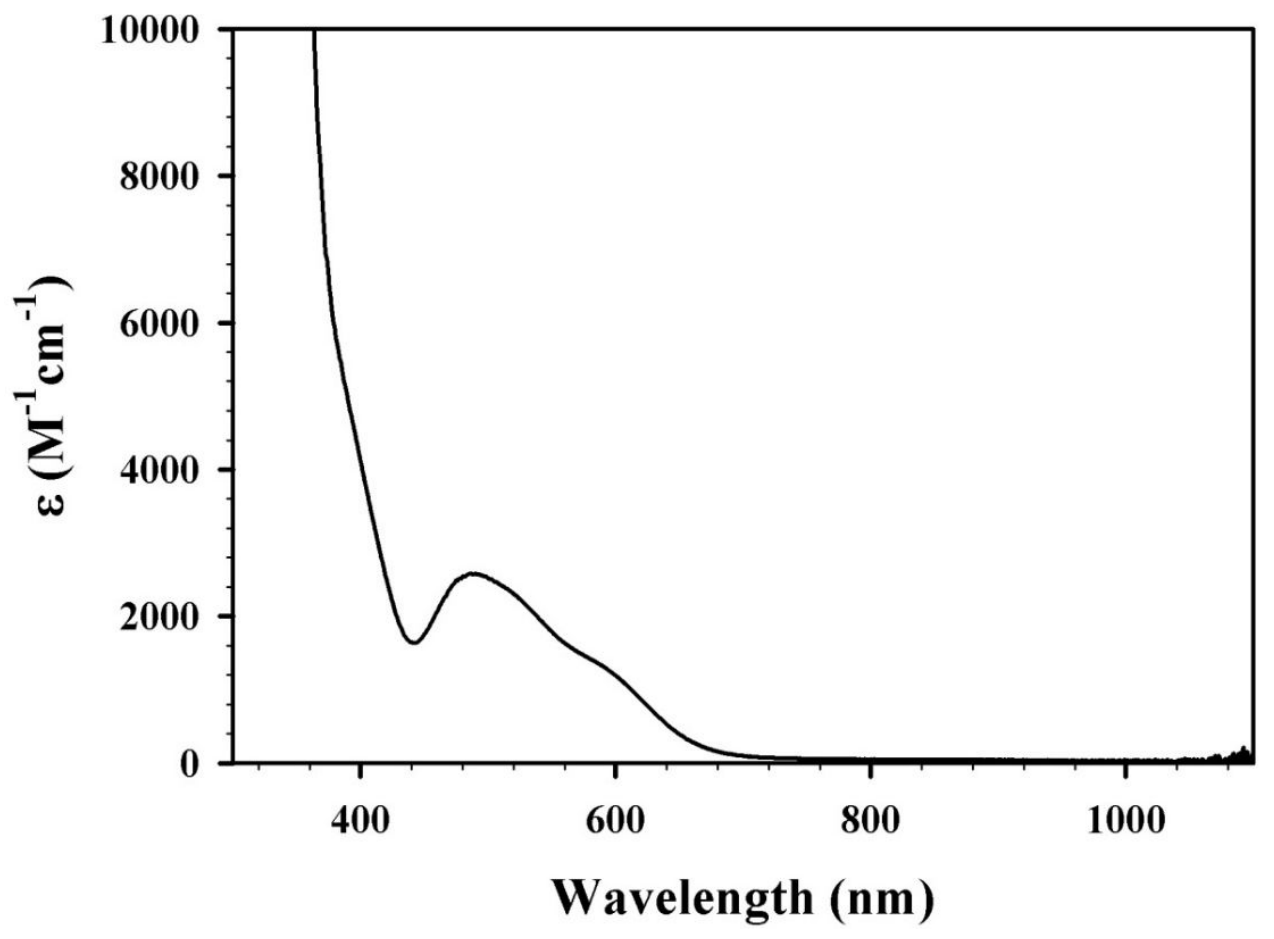

Figure S21. The UV-vis-NIR spectrum of $\left[\mathrm{NEt}_{4}\right]\left[\mathrm{Co}(\mathrm{PS} 2 *)_{2}\right](3)$ in $\mathrm{CH}_{2} \mathrm{Cl}_{2}$. 


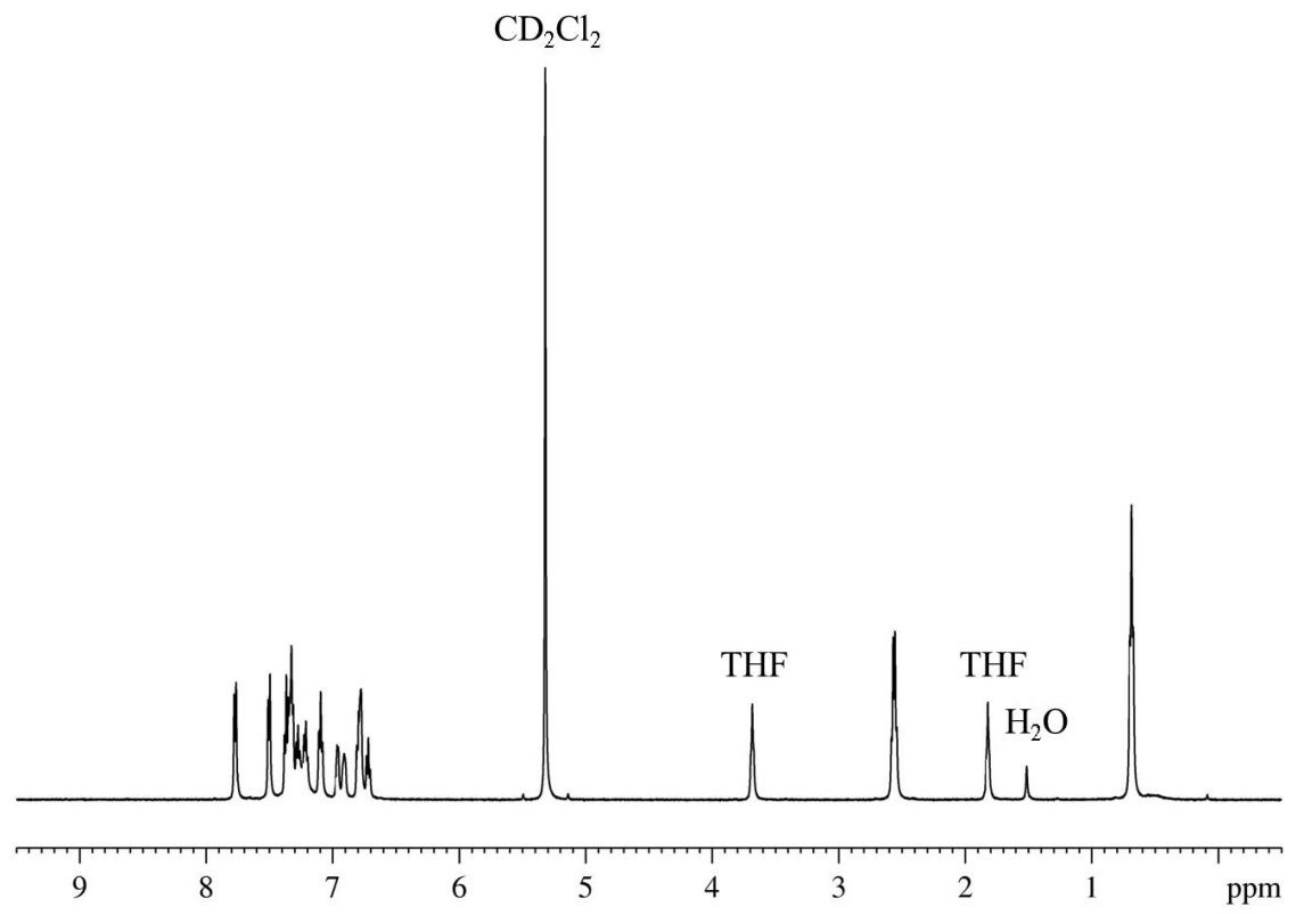

Figure S22. The ${ }^{1} \mathrm{H}$ NMR spectrum of $\left[\mathrm{NEt}_{4}\right]\left[\mathrm{Co}(\mathrm{PS} 2 *)_{2}\right](\mathbf{3})$ in $\mathrm{CD}_{2} \mathrm{Cl}_{2}$.

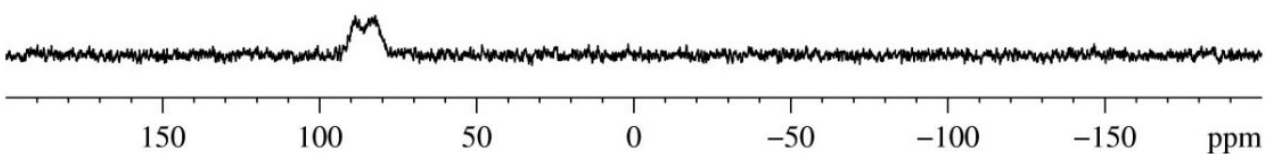

Figure S23. The ${ }^{31} \mathrm{P}$ NMR spectrum of $\left[\mathrm{NEt}_{4}\right]\left[\mathrm{Co}(\mathrm{PS} 2 *)_{2}\right](3)$ in $\mathrm{CD}_{2} \mathrm{Cl}_{2}$. 


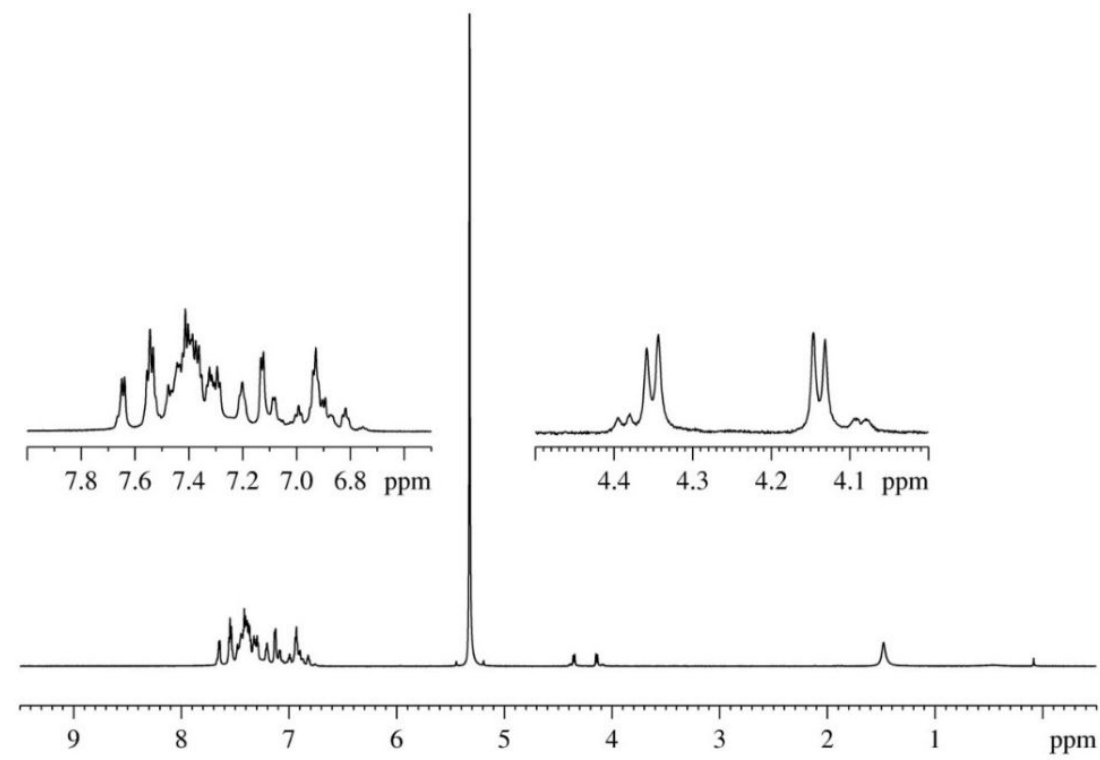

Figure S24. The ${ }^{1} \mathrm{H}$ NMR spectrum of $\left[\mathrm{Co}(\mathrm{PS} 2 *)\left(\mathrm{PSS}^{\mathrm{CH}} 2 \mathrm{Cl} *\right)\right]\left(4\right.$ and $\left.\mathbf{4}^{\prime}\right)$ in $\mathrm{CD}_{2} \mathrm{Cl}_{2}$. Inset: The ${ }^{1} \mathrm{H}$ NMR spectrum range at 4.0-4.5 ppm and 6.5-8.0 ppm.

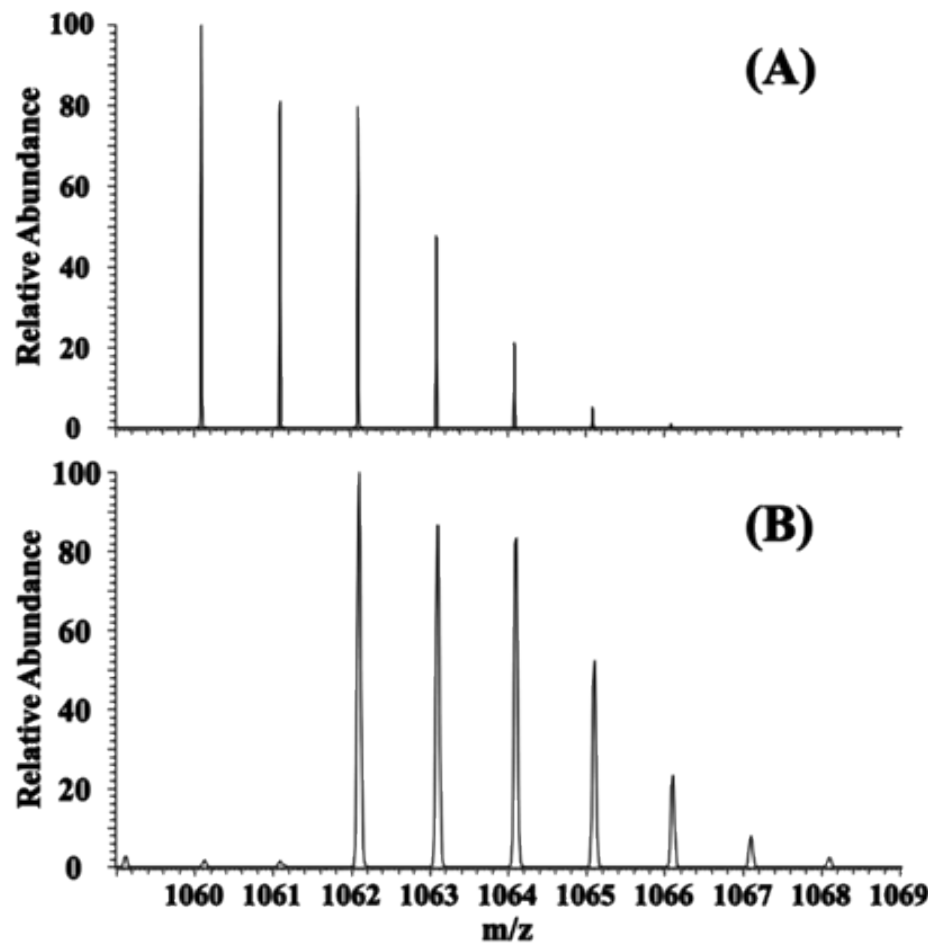

Figure S25. (A) ESI-MS spectrum of $\left[\mathrm{Co}\left(\mathrm{PS}^{2} *\right)\left(\mathrm{PSS}^{\mathrm{CH} 2 \mathrm{Cl} *}\right)\right]\left(4\right.$ and $\left.\mathbf{4}^{\prime}\right)$ obtained from the reaction of 3 and $\mathrm{CH}_{2} \mathrm{Cl}_{2}$, showing the isotope distribution at the $1060.09 \mathrm{~m} / \mathrm{z}$. (B) The spectrum obtained from the reaction of $\mathbf{3}$ and $\mathrm{CD}_{2} \mathrm{Cl}_{2}$, showing the isotope distribution at the $1062.09 \mathrm{~m} / \mathrm{z}$. 


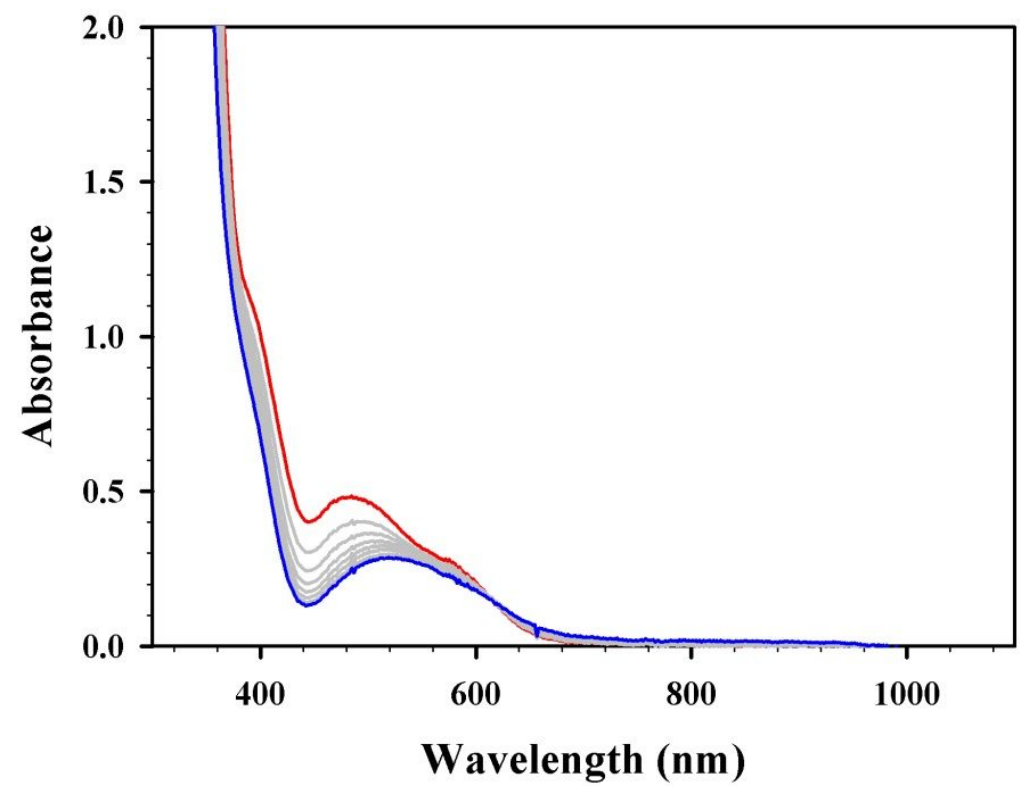

Figure S26. UV-vis-NIR spectra of complex 3 in $\mathrm{CH}_{3} \mathrm{CN}$ after the addition of 100 equivalents of benzylchloride. The spectrum was monitored over a 7-hour period: the initial (red line), the final spectrum (blue line).

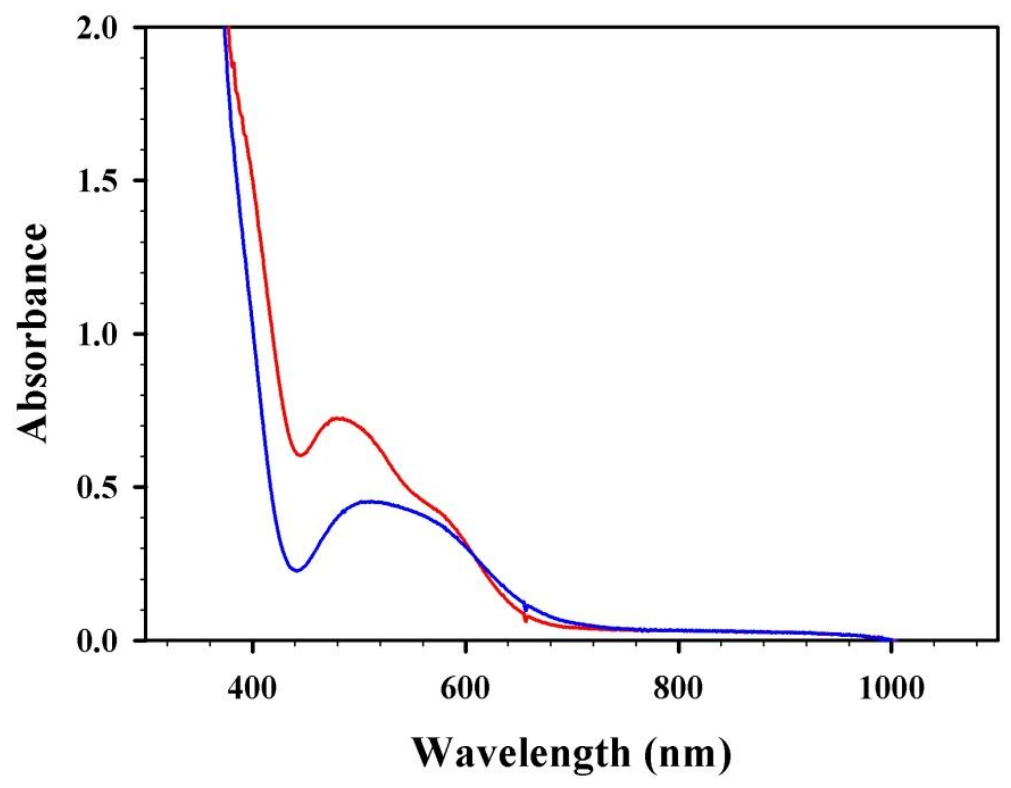

Figure S27. UV-vis-NIR spectra of complex 3 in $\mathrm{CH}_{3} \mathrm{CN}$ (red line) after the addition of 100 equivalents of $\mathrm{CH}_{3} \mathrm{I}$ (blue line), and the solution color from reddish-brown change to purple immediately. 


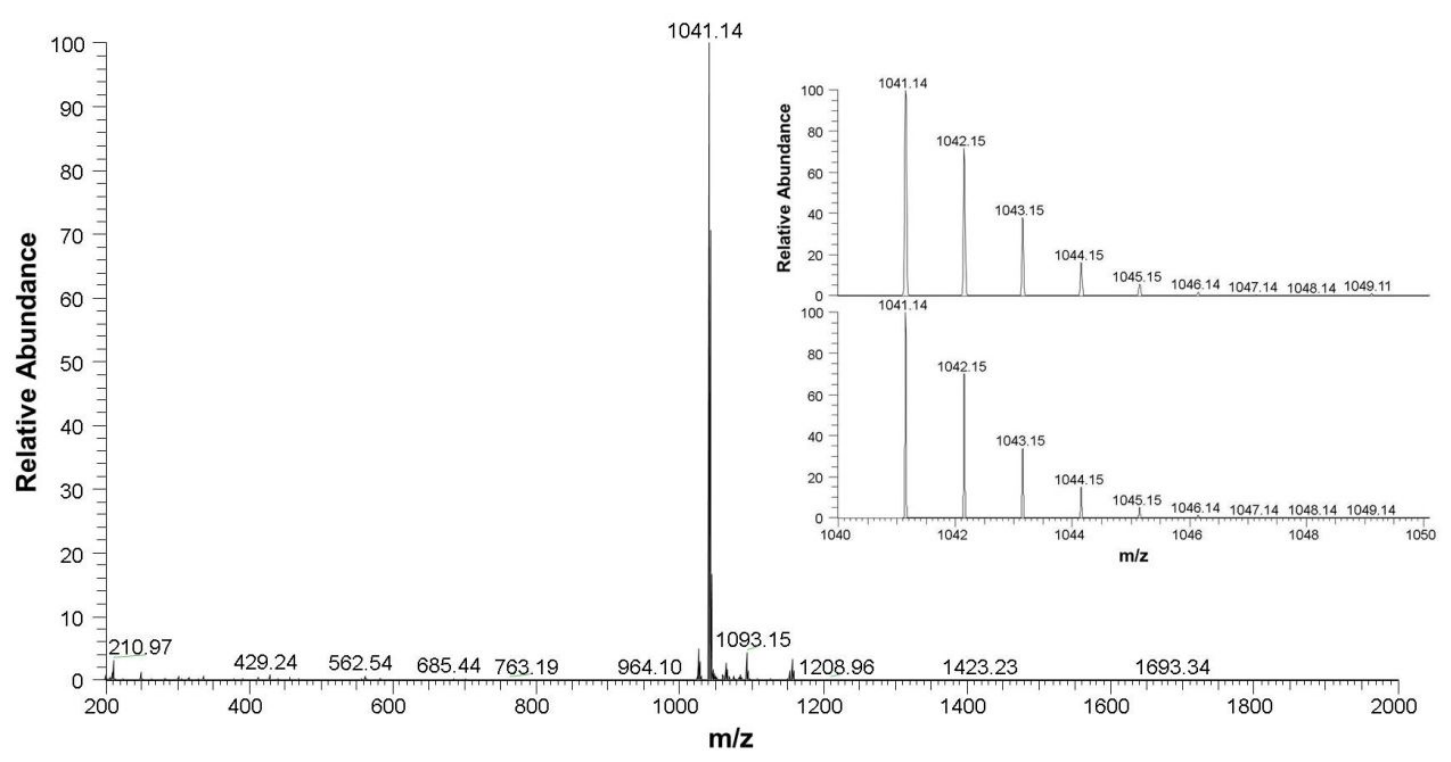

Figure S28. The ESI-MS spectrum of complex 3 with the addition of 100 equivalents of $\mathrm{CH}_{3} \mathrm{I}$ in $\mathrm{CH}_{3} \mathrm{CN}$. The molecular ion peaks display isotopic distribution at 1041.14 $m / z$ (inset: top), consistent with the calculated pattern of $\mathrm{CoC}_{62} \mathrm{H}_{48} \mathrm{P}_{2} \mathrm{~S}_{4}$ formulation (inset: bottom).

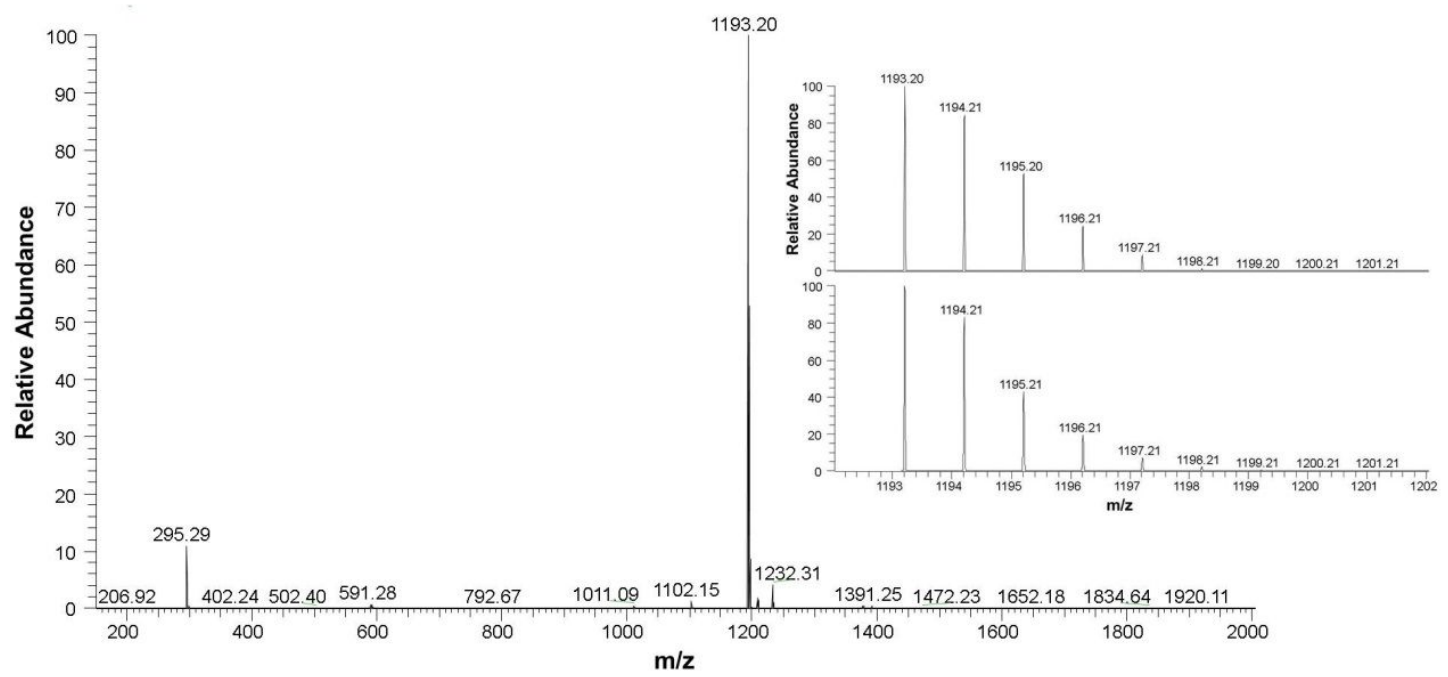

Figure S29. The ESI-MS spectrum of complex 3 with the addition of 100 equivalents of benzyl chloride in $\mathrm{CH}_{3} \mathrm{CN}$. The molecular ion peaks display isotopic distribution at $1193.20 \mathrm{~m} / z$ (inset: top), consistent with the calculated pattern of $\mathrm{CoC}_{74} \mathrm{H}_{56} \mathrm{P}_{2} \mathrm{~S}_{4}$ formulation (inset: bottom). 


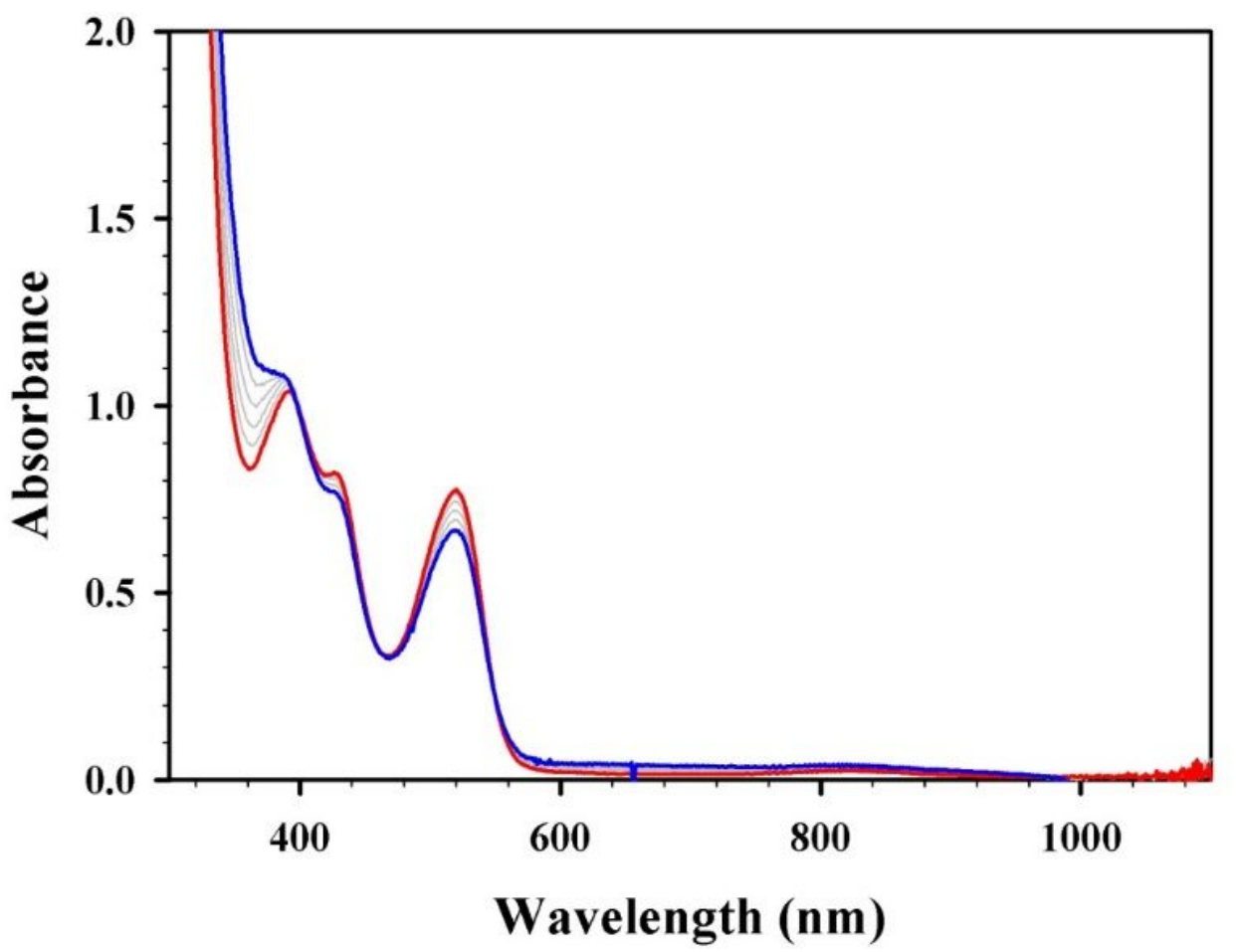

Figure S30. UV-vis-NIR spectra of complex 1 in $\mathrm{CH}_{2} \mathrm{Cl}_{2}$ (red line) after the addition of 100 equivalents of $\mathrm{CH}_{3} \mathrm{I}$. The spectrum was taken every 2 hours over a 10-hour period: initial (red line) and 10h (blue line). 
Table S1. Crystallographic data of [Co(PS1") $\left.)_{2}\right](\mathbf{1})$.

\begin{tabular}{|c|c|}
\hline & {$\left[\mathrm{Co}\left(\mathrm{PS}{ }^{\prime}{ }_{2}\right]\right.$} \\
\hline Chemical formula & $\mathrm{C}_{42} \mathrm{H}_{44} \mathrm{CoP}_{2} \mathrm{~S}_{2} \mathrm{Si}_{2}$ \\
\hline $\mathrm{Fw}$ & 789.94 \\
\hline$T, \mathrm{~K}$ & $150(2)$ \\
\hline Crystal system & Orthorhombic \\
\hline Space group & $P b c a$ \\
\hline$a, \AA$ & $12.7054(7)$ \\
\hline$b, \AA$ & $12.6295(6)$ \\
\hline$c, \AA$ & $24.8552(13)$ \\
\hline$\alpha$, deg & 90 \\
\hline$\beta$, deg & 90 \\
\hline$\gamma$, deg & 90 \\
\hline$V, \AA^{3}$ & $3988.3(4)$ \\
\hline$Z$ & 4 \\
\hline$D_{\text {cala }} / \mathrm{g} \mathrm{cm}{ }^{-3}$ & 1.316 \\
\hline$\mu\left(\mathrm{Mo}-\mathrm{K}_{\alpha}\right) / \mathrm{mm}^{-1}$ & 0.705 \\
\hline $\mathrm{GOF}^{\mathrm{a}}$ on $F^{2}$ & 1.288 \\
\hline $\mathrm{R}_{1},{ }^{\mathrm{b} \%}$ & 0.0582 \\
\hline $\mathrm{wR}{ }_{2}{ }^{\mathrm{co}} \%$ & 0.1151 \\
\hline
\end{tabular}

${ }^{\mathrm{a}} \mathrm{GOF}=\left\{\Sigma\left[w\left(F_{\mathrm{O}}{ }^{2}-F_{\mathrm{c}}{ }^{2}\right)^{2}\right] /(M-N)\right\} 1 / 2(M=$ number of reflections, $N=$ number of parameters refined) ${ }^{\mathrm{b}} R_{1}=\Sigma|| F_{\mathrm{O}}|-| F_{\mathrm{c}} \| / \Sigma|| F_{\mathrm{O}} \mid$.

${ } w_{2}=\left\{\Sigma\left[w\left(F_{\mathrm{O}}{ }^{2}-F_{\mathrm{c}}{ }^{2}\right)^{2}\right] / \Sigma\left[w\left(F_{\mathrm{O}}{ }^{2}\right)^{2}\right]\right\}^{1 / 2}$.

CCDC 1574445 
Table S2. Crystallographic data of $\left[\mathrm{NEt}_{4}\right]\left[\mathrm{Co}\left(\mathrm{PS}^{*}\right)_{2}\right] \cdot 2 \mathrm{CH}_{3} \mathrm{OH} \cdot 0.5 \mathrm{THF}$ (3. $\left.2 \mathrm{CH}_{3} \mathrm{OH} \cdot 0.5 \mathrm{THF}\right)$.

\begin{tabular}{|c|c|}
\hline & {$\left[\mathrm{NEt}_{4}\right]\left[\mathrm{Co}\left(\mathrm{PS}_{2} *\right)_{2}\right] \cdot 2 \mathrm{CH}_{3} \mathrm{OH} \cdot 0.5 \mathrm{THF}$} \\
\hline Chemical formula & $\mathrm{C}_{72} \mathrm{H}_{74} \mathrm{CoNO}_{2.50} \mathrm{P}_{2} \mathrm{~S}_{4}$ \\
\hline Fw & 1242.43 \\
\hline$T, \mathrm{~K}$ & $150(2)$ \\
\hline Crystal system & Monoclinic \\
\hline Space group & $P 2{ }_{1} / c$ \\
\hline$a, \AA$ & $16.9431(6)$ \\
\hline$b, \AA$ & $14.9890(6)$ \\
\hline$c, \AA$ & $24.3794(9)$ \\
\hline$\alpha, \operatorname{deg}$ & 90 \\
\hline$\beta, \operatorname{deg}$ & $92.1804(10)$ \\
\hline$\gamma, \operatorname{deg}$ & 90 \\
\hline$V, \AA^{3}$ & $6186.9(4)$ \\
\hline$Z$ & 4 \\
\hline$D_{\text {cala }} / \mathrm{g} \mathrm{cm}^{-3}$ & 1.334 \\
\hline$\mu\left(\mathrm{Mo}-\mathrm{K}_{\alpha}\right) / \mathrm{mm}^{-1}$ & 0.513 \\
\hline $\mathrm{GOF}^{\mathrm{a}}$ on $F^{2}$ & 1.057 \\
\hline $\mathrm{R}_{1},{ }^{\mathrm{b}} \%$ & 0.0345 \\
\hline $\mathrm{wR}_{2}, \mathrm{c} \%$ & 0.0727 \\
\hline
\end{tabular}

${ }^{\mathrm{a}} \mathrm{GOF}=\left\{\Sigma\left[w\left(F_{\mathrm{O}}{ }^{2}-F_{\mathrm{c}}{ }^{2}\right)^{2}\right] /(M-N)\right\} 1 / 2(M=$ number of reflections, $N=$ number of parameters refined)

${ }^{\mathrm{b}} R_{1}=\Sigma|| F_{\mathrm{O}}|-| F_{\mathrm{c}}|| / \Sigma|| F_{\mathrm{O}} \mid$.

${ }^{c_{w R}}=\left\{\Sigma\left[w\left(F_{\mathrm{O}}{ }^{2}-F_{\mathrm{c}}{ }^{2}\right)^{2}\right] / \Sigma\left[w\left(F_{\mathrm{O}}{ }^{2}\right)^{2}\right]\right\}^{1 / 2}$.

CCDC 1574262 
Table S3. Crystallographic data of $\left[\mathrm{Co}(\mathrm{PS} 2 *)\left(\mathrm{PSS}^{\mathrm{CH} 2 \mathrm{Cl}} *\right)\right] \cdot 5 \mathrm{CH}_{3} \mathrm{OH}\left(4 \cdot 5 \mathrm{CH}_{3} \mathrm{OH}\right)$.

\begin{tabular}{|c|c|}
\hline & {$\left[\mathrm{Co}\left(\mathrm{PS}^{2} *\right)\left(\mathrm{PSS}^{\mathrm{CH} 2 \mathrm{Cl} *}\right)\right] \cdot 5 \mathrm{CH}_{3} \mathrm{OH}$} \\
\hline Chemical formula & $\mathrm{C}_{66} \mathrm{H}_{60} \mathrm{ClCoO}_{5} \mathrm{P}_{2} \mathrm{~S}_{4}$ \\
\hline $\mathrm{Fw}$ & 1217.70 \\
\hline$T, \mathrm{~K}$ & $200(2)$ \\
\hline Crystal system & Monoclinic \\
\hline Space group & $P 2{ }_{1} / n$ \\
\hline$a, \AA$ & $16.0422(5)$ \\
\hline$b, \AA$ & $17.7557(5)$ \\
\hline$c, \AA$ & $21.3619(7)$ \\
\hline$\alpha, \operatorname{deg}$ & 90 \\
\hline$\beta, \operatorname{deg}$ & $93.7850(11)$ \\
\hline$\gamma, \operatorname{deg}$ & 90 \\
\hline$V, \AA^{3}$ & $6071.5(3)$ \\
\hline$Z$ & 4 \\
\hline$D_{\text {cala }} / \mathrm{g} \mathrm{cm}^{-3}$ & 1.332 \\
\hline$\mu\left(\mathrm{Mo}-\mathrm{K}_{\alpha}\right) / \mathrm{mm}^{-1}$ & 0.566 \\
\hline $\mathrm{GOF}^{\mathrm{a}}$ on $F^{2}$ & 1.094 \\
\hline $\mathrm{R}_{1}, \mathrm{~b} \%$ & 0.0751 \\
\hline $\mathrm{wR}_{2},{ }^{\mathrm{c}} \%$ & 0.1899 \\
\hline
\end{tabular}

${ }^{\mathrm{a}} \mathrm{GOF}=\left\{\Sigma\left[w\left(F_{\mathrm{O}}{ }^{2}-F_{\mathrm{C}}{ }^{2}\right)^{2}\right] /(M-N)\right\} 1 / 2(M=$ number of reflections, $N=$ number of parameters refined) ${ }^{\mathrm{b}} R_{1}=\Sigma|| F_{\mathrm{O}}|-| F_{\mathrm{c}} \| / \Sigma|| F_{\mathrm{O}} \mid$.

${ } w_{2}=\left\{\Sigma\left[w\left(F_{\mathrm{O}}{ }^{2}-F_{\mathrm{c}}{ }^{2}\right)^{2}\right] / \Sigma\left[w\left(F_{\mathrm{O}}{ }^{2}\right)^{2}\right]\right\}^{1 / 2}$.

CCDC 1574279 
Table S4. Crystallographic data of $\left[\mathrm{Co}(\mathrm{PS} 2 *)\left(\mathrm{PSS}^{\mathrm{CH} 2 \mathrm{Cl}} *\right)\right] \cdot \mathrm{CH}_{2} \mathrm{Cl}_{2}\left(4^{\prime} \cdot \mathrm{CH}_{2} \mathrm{Cl}_{2}\right)$.

\begin{tabular}{|c|c|}
\hline & {$\left[\mathrm{Co}(\mathrm{PS} 2 *)\left(\mathrm{PSS}^{\mathrm{CH} 2 \mathrm{Cl} *}\right)\right] \cdot \mathrm{CH}_{2} \mathrm{Cl}_{2}$} \\
\hline Chemical formula & $\mathrm{C}_{62} \mathrm{H}_{46} \mathrm{Cl}_{3} \mathrm{CoP}_{2} \mathrm{~S}_{4}$ \\
\hline Fw & 1146.45 \\
\hline$T, \mathrm{~K}$ & $150(2)$ \\
\hline Crystal system & Monoclinic \\
\hline Space group & $P 2{ }_{1} / n$ \\
\hline$a, \AA$ & $11.1538(5)$ \\
\hline$b, \AA$ & $17.7776(7)$ \\
\hline$c, \AA$ & $27.3622(11)$ \\
\hline$\alpha, \operatorname{deg}$ & 90 \\
\hline$\beta, \operatorname{deg}$ & $92.7969(16)$ \\
\hline$\gamma, \operatorname{deg}$ & 90 \\
\hline$V, \AA^{3}$ & $5419.1(4)$ \\
\hline$Z$ & 4 \\
\hline$D_{\text {cala }} / \mathrm{g} \mathrm{cm}^{-3}$ & 1.405 \\
\hline$\mu\left(\mathrm{Mo}-\mathrm{K}_{\alpha}\right) / \mathrm{mm}^{-1}$ & 0.718 \\
\hline $\mathrm{GOF}^{\mathrm{a}}$ on $F^{2}$ & 1.107 \\
\hline $\mathrm{R}_{1}, \mathrm{~b} \%$ & 0.0693 \\
\hline $\mathrm{wR}_{2},{ }^{\mathrm{c}} \%$ & 0.1976 \\
\hline
\end{tabular}

${ }^{\mathrm{a}} \mathrm{GOF}=\left\{\Sigma\left[w\left(F_{\mathrm{O}}{ }^{2}-F_{\mathrm{C}}{ }^{2}\right)^{2}\right] /(M-N)\right\} 1 / 2(M=$ number of reflections, $N=$ number of parameters refined) ${ }^{\mathrm{b}} R_{1}=\Sigma|| F_{\mathrm{O}}|-| F_{\mathrm{c}} \| / \Sigma|| F_{\mathrm{O}} \mid$.

${ }^{c_{w}} R_{2}=\left\{\Sigma\left[w\left(F_{\mathrm{O}}{ }^{2}-F_{\mathrm{c}}{ }^{2}\right)^{2}\right] / \Sigma\left[w\left(F_{\mathrm{O}}{ }^{2}\right)^{2}\right]\right\}^{1 / 2}$.

CCDC 1574278 
Table S5. Selected bond distances $(\AA)$ and bond angles (deg) of $\mathbf{1}$.

\begin{tabular}{|ll|ll|}
\hline \multicolumn{2}{|c|}{ bond distance $(\AA)$} & \multicolumn{2}{c|}{ bond angle $(\mathrm{deg})$} \\
\hline Co-S$(1) \# 1$ & $2.1518(7)$ & $\mathrm{S}(1) \# 1-\mathrm{Co}-\mathrm{S}(1)$ & $180.000(9)$ \\
\hline Co-S(1) & $2.1518(7)$ & $\mathrm{S}(1) \# 1-\mathrm{Co}-\mathrm{P}(1)$ & $91.34(3)$ \\
\hline Co-P(1) & $2.1922(7)$ & $\mathrm{S}(1)-\mathrm{Co}-\mathrm{P}(1)$ & $88.66(3)$ \\
\hline Co-P(1)\#1 & $2.1922(7)$ & $\mathrm{S}(1) \# 1-\mathrm{Co}-\mathrm{P}(1) \# 1$ & $88.66(3)$ \\
\hline & & $\mathrm{S}(1)-\mathrm{Co}-\mathrm{P}(1) \# 1$ & $91.34(3)$ \\
\hline & $\mathrm{P}(1)-\mathrm{Co}-\mathrm{P}(1) \# 1$ & 180.0 \\
\hline
\end{tabular}

Table S6. Selected bond distances $(\AA)$ and bond angles (deg) of $3 \cdot 2 \mathrm{CH}_{3} \mathrm{OH} \cdot 0.5 \mathrm{THF}$.

\begin{tabular}{|c|c|c|c|c|c|}
\hline \multicolumn{2}{|c|}{ bond distance $(\AA)$} & \multicolumn{4}{|c|}{ bond angle (deg) } \\
\hline Co-P(2) & $2.1450(5)$ & $\mathrm{P}(2)-\mathrm{Co}-\mathrm{P}(1)$ & $102.96(2)$ & $\mathrm{S}(2)-\mathrm{Co}-\mathrm{S}(1)$ & $93.66(2)$ \\
\hline Co-P(1) & $2.1602(5)$ & $\mathrm{P}(2)-\mathrm{Co}-\mathrm{S}(2)$ & $88.41(2)$ & $\mathrm{S}(4)-\mathrm{Co}-\mathrm{S}(1)$ & $89.38(2)$ \\
\hline Co-S(2) & $2.2629(5)$ & $\mathrm{P}(1)-\mathrm{Co}-\mathrm{S}(2)$ & $89.24(2)$ & $\mathrm{P}(2)-\mathrm{Co}-\mathrm{S}(3)$ & $83.55(2)$ \\
\hline Co-S(4) & $2.2754(5)$ & $\mathrm{P}(2)-\mathrm{Co}-\mathrm{S}(4)$ & $88.93(2)$ & $\mathrm{P}(1)-\mathrm{Co}-\mathrm{S}(3)$ & $172.91(2)$ \\
\hline Co-S(1) & $2.2952(5)$ & $\mathrm{P}(1)-\mathrm{Co}-\mathrm{S}(4)$ & $88.92(2)$ & $\mathrm{S}(2)-\mathrm{Co}-\mathrm{S}(3)$ & $88.12(2)$ \\
\hline \multirow[t]{3}{*}{ Co-S(3) } & $2.3103(5)$ & $\mathrm{S}(2)-\mathrm{Co}-\mathrm{S}(4)$ & $176.35(2)$ & $\mathrm{S}(4)-\mathrm{Co}-\mathrm{S}(3)$ & $94.06(2)$ \\
\hline & & $\mathrm{P}(2)-\mathrm{Co}-\mathrm{S}(1)$ & $170.42(2)$ & $\mathrm{S}(1)-\mathrm{Co}-\mathrm{S}(3)$ & $87.17(2)$ \\
\hline & & $\mathrm{P}(1)-\mathrm{Co}-\mathrm{S}(1)$ & $86.43(2)$ & & \\
\hline
\end{tabular}

Table S7. Selected bond distances $(\AA)$ and bond angles (deg) of $4 \cdot 5 \mathrm{CH}_{3} \mathrm{OH}$.

\begin{tabular}{|c|c|c|c|}
\hline bond distance $(\AA)$ & \multicolumn{3}{|c|}{ bond angle (deg) } \\
\hline Co-P(1) 2.179(1) & $\mathrm{P}(1)-\mathrm{Co}-\mathrm{P}(2)$ & $102.24(5)$ & $\mathrm{S}(4)-\mathrm{Co}-\mathrm{S}(1)$ \\
\hline Co-P(2) 2.180(1) & $\mathrm{P}(1)-\mathrm{Co}-\mathrm{S}(2)$ & $87.06(5)$ & $\mathrm{P}(1)-\mathrm{Co}-\mathrm{S}(3)$ \\
\hline Co-S(2) 2.245(1) & $\mathrm{P}(2)-\mathrm{Co}-\mathrm{S}(2)$ & $88.88(5)$ & $\mathrm{P}(2)-\mathrm{Co}-\mathrm{S}(3)$ \\
\hline Co-S(4) 2.266(1) & $\mathrm{P}(1)-\mathrm{Co}-\mathrm{S}(4)$ & $92.39(5)$ & $\mathrm{S}(2)-\mathrm{Co}-\mathrm{S}(3)$ \\
\hline Co-S(1) 2.276(1) & $\mathrm{P}(2)-\mathrm{Co}-\mathrm{S}(4)$ & $89.20(5)$ & $\mathrm{S}(4)-\mathrm{Co}-\mathrm{S}(3)$ \\
\hline Co-S(3) 2.280(1) & $\mathrm{S}(2)-\mathrm{Co}-\mathrm{S}(4)$ & $177.85(6)$ & $\mathrm{S}(1)-\mathrm{Co}-\mathrm{S}(3) \quad 83.41(5)$ \\
\hline$S(4)-C(61)$ & $\mathrm{P}(1)-\mathrm{Co}-\mathrm{S}(1)$ & $87.96(5)$ & $\mathrm{C}(61)-\mathrm{S}(4)-\mathrm{Co} 110.1(3)$ \\
\hline $\mathrm{Cl}(1)-\mathrm{C}(61)$ & $\mathrm{P}(2)-\mathrm{Co}-\mathrm{S}(1)$ & $169.70(6)$ & $\mathrm{Cl}(1)-\mathrm{C}(61)-\mathrm{S}(4) 112.3(4)$ \\
\hline & $\mathrm{S}(2)-\mathrm{Co}-\mathrm{S}(1)$ & $93.15(5)$ & \\
\hline
\end{tabular}


Table S8. Selected bond distances $(\AA)$ and bond angles (deg) of $4^{\prime} \cdot \mathrm{CH}_{2} \mathrm{Cl}_{2}$.

\begin{tabular}{|c|c|c|c|c|}
\hline \multicolumn{2}{|c|}{ bond distance $(\AA)$} & \multicolumn{3}{|c|}{ bond angle (deg) } \\
\hline Co-P(1) 2. & $2.160(1)$ & $\mathrm{P}(1)-\mathrm{Co}-\mathrm{P}(2)$ & $103.75(4)$ & $\mathrm{S}(2)-\mathrm{Co}-\mathrm{S}(1)$ \\
\hline Co-P(2) 2. & $2.166(1)$ & $\mathrm{P}(1)-\mathrm{Co}-\mathrm{S}(4)$ & $89.27(4)$ & $\mathrm{P}(1)-\mathrm{Co}-\mathrm{S}(3)$ \\
\hline Co-S(4) 2. & $2.264(1)$ & $\mathrm{P}(2)-\mathrm{Co}-\mathrm{S}(4)$ & $88.44(4)$ & $\mathrm{P}(2)-\mathrm{Co}-\mathrm{S}(3)$ \\
\hline $\mathrm{Co}-\mathrm{S}(2) 2$. & $2.264(1)$ & $\mathrm{P}(1)-\mathrm{Co}-\mathrm{S}(2)$ & $88.65(4)$ & $\mathrm{S}(4)-\mathrm{Co}-\mathrm{S}(3)$ \\
\hline Co-S(1) 2. & $2.275(1)$ & $\mathrm{P}(2)-\mathrm{Co}-\mathrm{S}(2)$ & $90.97(4)$ & $\mathrm{S}(2)-\mathrm{Co}-\mathrm{S}(3)$ \\
\hline $\mathrm{Co}-\mathrm{S}(3) 2$. & $2.295(1)$ & $\mathrm{S}(4)-\mathrm{Co}-\mathrm{S}(2)$ & $177.64(4)$ & $\mathrm{S}(1)-\mathrm{Co}-\mathrm{S}(3) \quad 86.24(4)$ \\
\hline$S(3)-C(61)$ & $1.785(7)$ & $\mathrm{P}(1)-\mathrm{Co}-\mathrm{S}(1)$ & $85.02(4)$ & $\mathrm{C}(61)-\mathrm{S}(3)-\mathrm{Co} 109.8(2)$ \\
\hline \multicolumn{2}{|l|}{$\mathrm{C}(61)-\mathrm{Cl}(1)$} & $\mathrm{P}(2)-\mathrm{Co}-\mathrm{S}(1)$ & $170.23(4)$ & $\mathrm{Cl}(1)-\mathrm{C}(61)-\mathrm{S}(3) 113.9(4)$ \\
\hline & & $\mathrm{S}(4)-\mathrm{Co}-\mathrm{S}(1)$ & $87.37(4)$ & \\
\hline
\end{tabular}

